Florida State University College of Law

Scholarship Repository

Scholarly Publications

1992

\title{
The Kantian Theory of International Law
}

Fernando R. Tesón

Florida State University College of Law

Follow this and additional works at: https://ir.law.fsu.edu/articles

Part of the International Law Commons, Law and Philosophy Commons, and the Public Law and Legal Theory Commons

\section{Recommended Citation}

Fernando R. Tesón, The Kantian Theory of International Law, 92 COLUM. L. REV. 53 (1992),

Available at: https://ir.law.fsu.edu/articles/31

This Article is brought to you for free and open access by Scholarship Repository. It has been accepted for inclusion in Scholarly Publications by an authorized administrator of Scholarship Repository. For more information, please contact efarrell@law.fsu.edu. 


\title{
THE KANTIAN THEORY OF INTERNATIONAL LAW
}

\author{
Fernando R. Tesón*
}

\section{INTRODUCTION}

This Article defends the view, first developed by Immanuel Kant, that international law and domestic justice are fundamentally connected. 1 Despite the recent prominence of the international law of human rights, the dominant discourse in international law fails to recognize the important normative status of the individual. Traditional international legal theory focuses upon the rights and duties of states and rejects the contention that the rights of states are merely derivative of the rights and interests of the individuals who reside within them. Accordingly, international legitimacy and sovereignty are a function of whether the government politically controls the population, rather than whether it justly represents its people. This statist conceptualization of international law argues for a dual paradigm for the ordering of individuals: one domestic, the other international. Justice and legitimacy are conceptually separate. It may well be that domestic systems strive to promote justice; but international systems only seek order and compliance.

International law thus conceived, however, is incapable of serving as the normative framework for present or future political realities. ${ }^{2}$

* Professor of Law, Arizona State University. J.D., University of Buenos Aires; Licencié en Droit International, Université Libre de Bruxelles; S.J.D., Northwestern University. This article is excerpted from my book The Philosophy of International Law (Westview Press, forthcoming). My thanks to Kirsten Spalding, David Kaye, and to the members of the Moral, Political, and Legal Philosophy Research Group here at Arizona State: Jeffrie Murphy, David Kader, Larry Winer, Peter de Marneffe, Joan McGregor, Richard Dagger, Jack Crittendon, Charles Dresser, and Al D'Amico. All these people contributed helpful comments and criticisms. My thanks also to Harold A. Neu from the Columbia Law Review for his excellent suggestions.

Copyright (C 1991 Fernando R. Tesón.

1. Immanuel Kant's most important work on international relations is Immanuel Kant, To Perpetual Peace: A Philosophical Sketch [1795], in Perpetual Peace and Other Essays 107 (Ted Humphrey trans., 1983) [hereinafter Kant, Perpetual Peace]. Kant elaborates on his international theory elsewhere, see Idea for a Universal History with a Cosmopolitan lntent [1784], in Perpetual Peace and Other Essays, supra, at 29, 34-39 [hereinafter Kant, Universal History]; On the Proverb: That May be True in Theory, But Is of No Practical Use [1793], in Perpetual Peace and Other Essays, supra, at 61, 85-89 [hereinafter Kant, Theory and Practice]. The best summary of Kant's moral theory by Kant himself is Immanuel Kant, Groundwork of the Metaphysic of Morals (H.J. Paton trans., Harper Torchbook ed. 1964) [hereinafter Kant, Groundwork]. A very useful secondary source for Kant's moral theory is Roger J. Sullivan, Immanuel Kant's Moral Theory (1989). This article relies extensively on Professor Sullivan's account.

2. I am referring to the liberal revolutionary changes in the last 20 years, including the lberian Peninsula in the 1970s; Latin America (led by Argentina) in the middle 1980s; and Central Europe since 1989. See Dankwart A. Rustow, Democracy: A Global Revolution?, Foreign Aff., Fall 1990, at 75. On Latin America, see 4 Democracy In De- 
While it is understandably hard for lawyers to forsake the statist assumptions of classic international legal discourse, new times call for a fresh conceptual and ethical language. ${ }^{3}$ A liberal theory of international law can hardly be reconciled with the statist approach. ${ }^{4}$ Liberal theory commits itself instead to normative individualism, to the premise that the primary normative unit is the individual, not the state. ${ }^{5}$ The end of states and governments is to benefit, serve, and protect their components, human beings; and the end of international law must also be to benefit, serve, and protect human beings, and not its components, states and governments. Respect for states is merely derivative of respect for persons. In this way, the notion of state sovereignty is redefined: the sovereignty of the state is dependent upon the state's domestic legitimacy; and therefore the principles of international justice must be congruent with the principles of internal justice. ${ }^{6}$

Immanuel Kant was the first to defend this thesis, ${ }^{7}$ and for that reason it will be called the Kantian theory of international law. This Article reconstructs and examines Kant's theory as put forth in his famous essay Perpetual Peace. Part I addresses the controversy regarding the essay's structure and organization, and argues that Kant developed a normative philosophy of international law, not merely a practical political program. Part II shows that Kant's reason for respecting states stemmed from concerns about individual freedom, not from holistic claims about the state as a moral person. Part III presents and defends

veloping Countries: Latin America (Larry Diamond, et al. eds., 1989); on Europe, see Vents D'Est: Vers l'Europe des Etats de droit (Pierre Grémion \& Pierre Hassner eds., 1990).

3. The growing number of legal scholars who are challenging the statist paradigm include Anthony D'Amato, The Invasion of Panama Was a Lawful Response to Tyranny, 84 Am. J. Int'l L. 516 (1990); W. Michael Reisman, Sovereignty and Human Rights in Contemporary International Law, 84 Am. J. Int'l L. 866 (1990).

4. The word "liberal" is notorious for its multiple meanings in politics and political theory. I mean "liberal theory" here simply as a theory of politics founded upon individual freedom, respect for individual preferences, and individual autonomy. As such, it encompasses a broad spectrum of actual political positions, from social democrats to libertarians.

5. For a survey of the different meanings of "individualism," see Steven Lukes, Individualism (1973). The notion of individualism defended in this Article is both methodological and normative. Methodological individualism contends that social science explanations should only be made in terms of individuals, see id. at 110-22. Normative individualism insists that our moral concepts should be referred in the last analysis to individual rights and interests-this is not to be confused with ethical egoism, which is a substantive moral doctrine, see id. at 99-106.

6. I have elsewhere argued for the same thesis using a modified Rawlsian model. See Fernando R. Tesón, International Obligation and the Theory of Hypothetical Consent, 15 Yale J. Int'l L. 84, 109-18 (1990).

7. Kant was the first to suggest human rights as the basis of international law, but not the first to propose an international alliance or organization. In this latter sense, the pioneer work is C.I. Castel de Saint-Pierre, Selections from the Second Edition of the Abrégé du Projet de Paix Perpétuelle (H. Hale Bellot trans., 1927), reprinted in Peace Projects of the Eighteenth Century (Garland ed., 1974). 
the two Kantian arguments for the international human rights imperative. First, an international community of just, democratic states is the best guarantee for international peace because internal freedom at home is causally related to peaceful behavior abroad. Second, international law requires respect for human rights because the just civic society is the ultimate goal of all political arrangements. The argument for human rights is universal since it is derived from the Kantian categorical imperative. ${ }^{8}$ These two arguments link international law to human rights and individual autonomy, not to national interest, rights of governments, or other notions similarly rooted in the primacy of state sovereignty. Part IV examines the nature of the liberal alliance proposed by Kant. Kant's choice of a decentralized system of international authority and enforcement is discussed and defended. This Part also examines the place of war within the theory, showing an inconsistency in Kant's views on war, and proposing a modified version. Part V defends the Kantian theory of international law against recent challenges to the idea that justice should be a component of international legitimacy. This Part also sets forth some conclusions and suggestions for practical reforms in accordance with the theory.

While offering a modern reconstruction of Kant's thesis rather than a meticulously faithful account of what Kant meant, the interpretation of Kant suggested in this Article is accurate, whether one wants to confine oneself to the text of Perpetual Peace, or one views his discussion of international law against the backdrop provided by Kant's general moral theory. To be sure, this Article departs from Kant on a few important points, ${ }^{9}$ but the main thrust of his account remains intact.

It is not surprising that Immanuel Kant's philosophy is cited with renewed frequency in many international fora. He is conventionally seen as the pioneering advocate of an international organization capable of securing a lasting peace. Commentators have justly praised Kant as the one philosopher who, in his effort to contest the prevailing views upholding the absolute right of governments to wage war, foreshadowed modern conceptions of international law associated with the United Nations. ${ }^{10}$ The novelty of his proposals explains why Kant's contribution has been regarded as avant la lettre political advocacy for the United Nations and peaceful world order. ${ }^{11}$ Nevertheless, Kant accomplished far more. He developed a subtle, rich, and innovative the-

8. For a discussion of Kant's categorical imperative, see infra notes $48-71$ and accompanying text.

9. See notes $65-68,167-170,199-220$ and accompanying text.

10. For a comparison between Kant's proposals and the precepts of the U.N. Charter, see Carl J. Friedrich, Inevitable Peace 33 (1948) (U.N. Charter in many respects mirrors Kant's conditions for world order); Wolfgang Schwarz, Kant's Philosophy of Law and International Peace, 23 Phil. \& Phenomenological Res. 71, 76-78 (1962).

11. See A.C. Armstrong, Kant's Philosophy of Peace and War, 28 J. Phil. 197, 201-04 (1931) (Kant's proposals for world peace "run closely parallel to those of 20th century"); see also W.B. Gallie, Philosophers of Peace and War 11-12 (1978) (Kant's 
ory of international law, one that was so much ahead of its time that even admirers were blind to its importance. Kant's originality stems not so much from predicting the rise of a global international organization, but from having been the first to show the strong links between international peace and personal freedom, and between arbitrary government at home and aggressive behavior abroad. Not only did he have the vision to predict modern international organization for the maintenance of peace; he also explained, for the first time, the connection between domestic freedom and the foundations of international law. In essence, he foresaw the human rights revolution of the twentieth century.

\section{The Structure of Perpetual PeAce}

Perpetual Peace was published in 1795 and was one of Immanuel Kant's last philosophical works. ${ }^{12}$ It is a relatively short essay that was meant for popular reading. ${ }^{13}$ Kant was not very good at writing for the general public, however, and the essay suffers as a consequence: the arguments are at times too concise and the writing often obscure. ${ }^{14}$ Nonetheless, Kant's genius pervades the essay. ${ }^{15}$ It had immediate success, and Kant's authority has been invoked frequently by advocates of pacifism and internationalism throughout the nineteenth and twentieth centuries. ${ }^{16}$ While there are many interpretations of Perpetual Peace, almost all commentators agree that in this short essay Kant made a subtle, rich, and lasting contribution both to the theory of international law and to the causes of justice and peace. The themes developed in Perpetual Peace have extraordinary contemporary relevance. It is no surprise that interest in the essay has been revived recently. Even the President of the former Soviet Union referred to Kant's work in his speech accepting the Nobel Peace Prize. ${ }^{17}$

Perpetual Peace contains six "Preliminary Articles," three "Definitive Articles," and two long "Addenda," the most important of which is "On the Guarantee of Perpetual Peace."18 The structural organization

vision was both "original" and "unique"). Although I differ with Professor Gallie in important ways, I have benefitted greatly from reading his excellent discussion of Kant.

12. See supra note 1.

13. See Gallie, supra note II, at 8-9.

14. For an account of Kant's background and the history of his interest in political philosophy, see Gallie, supra note 11, at 12-17.

15. In the words of Kenneth Waltz, Kant's mode of analysis is "rigorous and yet subtle, his style difficult but clear, his writing crabbed and still, as Goethe said, sometimes slyly ironic and even eloquent." Kenneth N. Waltz, Kant, Liberalism, and War, 56 Am. Pol. Sci. Rev. 331, 331 (1962).

16. See Armstrong, supra note 1I, at 197-98.

17. See Gorbachev Skips Nobel Awards, Chi. Trib., Dec. 11, 1990, at 4.

18. The text of the Articles with their headings is as follows:

First Section Which Contains the Preliminary Articles for Perpetual Peace Among Nations 
of Perpetual Peace raises two questions, the answer to which may provide insight into Kant's intent: Why is the essay put in the form of articles, like a treaty? What meaning, if any, should we ascribe to the categories of "preliminary" and "definitive" articles?

The selection of the format indicates that Kant intended to offer a programmatic formula for peace, rather than a philosophical analysis of the nature of international law and relations. Indeed, he wanted politicians to follow his advice-he specifically enjoins governments to take advice from philosophers. ${ }^{19}$ Thus, the form of the essay, at least in part, suggests that Kant wanted to draft a model treaty of some sort, ${ }^{20}$ with specific provisions to be honored by all signatories. However, he only partially succeeded: Perpetual Peace, as written, seems to suffer from a fundamental ambiguity. While the essay can be viewed as an unattainable moral ideal to which states ought to aspire in their international relations, ${ }^{21}$ it is preferably treated as an attempt to explicate international moral principles-the principles that should underlie the

1) No treaty of peace that tacitly reserves issues for a future war shall be held valid.

2) No independent nation, be it large or small, may be acquired by another nation by inheritance, exchange, purchase, or gift.

3) Standing armies (miles perpetus) shall be gradually abolished.

4) No national debt shall be contracted in connection with the foreign affairs of the nation.

5) No nation shall forcibly interfere with the constitution and government of another.

6) No nation at war with another shall permit such acts of war as must make mutual trust impossible during some future time of peace: Such acts include the use of Assassins (percussores), Poisoners (venefici); breach of surrender, instigation of treason (perduellio) in the opposing nation, etc.

Second Section Which Contains the Definitive Articles for Perpetual Peace Among Nations

1) The civil constitution of every nation should be republican.

2) [International law] shall be based on a federation of free states.

3) Cosmopolitan [Law] shall be limited to conditions of universal hospitality.

Kant, Perpetual Peace, supra note I, at 107-I8. In the Second and Third Definitive Articles, I prefer to use the word "law" rather than Humphrey's "right." The word "Recht" used in the original is ambiguous (as are the words "derecho" in Spanish and "droit" in French) and it may be translated as "law" or as "right," depending on the context. It is clear from the context in Perpetual Peace that Kant is referring to the objective international order, the "law," and not to "right" in the subjective sense. The German word "Volkerrecht" is ordinarily translated as "international law," not "international right." A better translation is offered by Carl Friedrich in Immanuel Kant, The Philosophy of Kant 44 I (Carl J. Friedrich ed., 1949) ("law of nations").

19. Kant, Perpetual Peace, supra note 1, at 126. But $\mathrm{cf}$. Waltz, supra note I5, at 339-40 (Kant "was not engaged in the puerile task of telling men of affairs to stop behaving badly").

20. See F.H. Hinsley, Power and the Pursuit of Peace 66 (1963).

21. See Waltz, supra note 15 , at $334,339-40$. This ambiguity is quite distinct from differences of interpretation about the essay's substantive content, discussed below. See infra notes 23-34 and accompanying text. 
relations among nations. Kant was a philosopher, not a mere pamphleteer. ${ }^{22}$ There is also a call for political action, to be sure: it is the one that flows naturally from his normative theory of international law. Thus, the essay is both conceptual and normative; it attempts to draw applied international legal principles from an understanding of the underlying philosophical nature of international relations.

The second organizational issue is what meaning to attribute to the categories "preliminary" and "definitive." Some commentators have interpreted the Preliminary Articles to be those which might have served as the legal foundation of international peace, or as a statement of international law as it ought to be; whereas the Definitive Articles are interpreted to be the political premises and safeguards, without which no state could be expected to comply with the earlier articles. ${ }^{23}$ For these writers, the Preliminary Articles are the solution, not a statement of the necessary preconditions to establishing the framework for a lasting peace. ${ }^{24}$

The reader may think that this debate is highly formalistic, exegetic, and overly textual. On the contrary, the debate over the purpose of Kant's choice of structure for Perpetual Peace is critical to an analysis of the work itself. Commentators in the realist tradition, who emphasize the primacy of the state as the international actor, exalt the Preliminary Articles. ${ }^{25}$ Indeed, the key pro-government rule, nonintervention, is embodied in one of the Preliminary Articles. In addition, Kant's commentary ostensibly relies on the analogy of the state as a moral person, which is a favorite theoretical device of realists. ${ }^{26}$ In contrast, each of the three Definitive Articles enshrines in different ways the primacy of individual freedom and the logically consistent unity of purpose of international and domestic law. ${ }^{27}$ Thus, a reading of Perpetual Peace that emphasizes the Preliminary Articles leads to a realist or statist interpretation that gives primacy to states and governments over individuals; whereas a reading that relies on the Definitive Articles leads to an interpretation that gives the priority to human rights over the power of the state as a foundation of international law.

22. See Karl Jaspers, Philosophy and the World 113-17 (E.B. Ashton trans., 1963) (Kant sets forth principles underlying international law, not political program). But see Waltz, supra note 15, at 334 ('Kant does set forth 'shoulds' and 'oughts' of state behavior.").

23. See Hinsley, supra note 20 , at 69 ; Gallie, supra note 11 , at 9-10.

24. See Hinsley, supra note 20, at 66-69.

25. See id. at 69 (arguing that Preliminary Articles are "a statement . . . of Kant's solution"). Hinsley flatly rejects the First Definitive Article-the requirement that all states be republican-by observing that "[i]t is impossible to overlook the lameness of [Kant's] conclusion [that republican states are more likely to be peaceful]." Id. at 7 I. His views are characteristic of the discomfort felt toward Kant's revolutionary humanism by those who cling to a statist world view and as a result adopt a statist reading of Kant.

26. For further discussion, see infra Part II.D.

27. See infra Parts II and III. 
The realist interpretation seems dubious. According to Kant, no perpetual peace can be achieved unless states are internally free and agree on an alliance or federation; ${ }^{28}$ therefore, it does not seem that adherence to the Preliminary Articles alone would have sufficed to maintain peace even among the 18th century European powers. The better interpretation of the Preliminary Articles is that they are those urgent agreements that should enter into force if the state of nature ${ }^{29}$ among states is to progress toward the formation of a federation that mirrors the relation of men under a civil constitution. The Preliminary Articles describe the most pressing steps to be taken if we want subsequently to proceed toward the lasting solution. ${ }^{30}$

In contrast, the substantive solutions, the institutional features of an effective and just international organization, are contained in the Definitive Articles. When Kant wrote "definitive," he meant what the word implies-a structure providing the final and conclusive solution to the problem of international relations. The Preliminary Articles do not even provide for the everlasting peace that Kant envisioned, which is included in the Second Definitive Article. Moreover, the Definitive Articles-which, as conceded by one of the above mentioned realist commentators, contain "Kant's most original political thinking"31_are

\section{See infra Part III.}

29. Commentators have emphasized how much Kant owed to Rousseau. See Gallie, supra note 11, at 17. Yet, Kant's conception of the state of nature as the pre-civil state of human beings before the formation of the state is, in different ways, closer to that of Hobbes and Locke. There are striking similarities and contrasts between Kant's conception of the state of nature and that of each of the great English philosophers. Kant shares with Hobbes the belief in the evil propensities of men and their tendency to immoral social conduct. See, e.g., Kant, Universal History, supra note 1, at 31; see also Sullivan, supra note 1, at 238-39 (Kant believed that "everyone is infected by the tendency to evil"). But Kant did have tremendous faith in reason. See Kant, Universal History, supra note 1, at 31 ("[A]s a class of rational beings ... [humanity] is destined to develop its capacities to perfection."). In contrast, Rousseau believed that man in the state of nature was ignorant of vice. See Jean-Jacques Rousseau, A Discourse on the Origin of Inequality, in The Social Contract and Discourse, 27, 66 (G.D.H. Cole trans., 1973). On the other hand, Kant shares with Locke the belief in morality predating the social contract (contrary to Hobbes). In Locke this takes the simple form of natural rights; whereas in Kant this innate morality is anchored in individual reason and autonomy. See Kant, Universal History, supra note 1, at 29-31. Finally, for both Kant and Locke, but not for Hobbes, the purpose of the state is to protect the citizen's freedom. See Thomas Hobbes, Leviathan 98-102 (Michael Oakeshott ed., 1962) (1651); David P. Gauthier, The Logic of Leviathan: The Moral and Political Theory of Thomas Hobbes 134-46 (1969); John Locke, Two Treatises of Government 350-53 (Peter Laslett ed., student ed. 1988) (1698). The analogy for the state of nature in international relations is qualified, however. The Kantian theory insists that individual morality, and therefore individual freedom, not "state" morality, predates the creation of international law.

30. See Schwarz, supra note 10, at 75; Thomas L. Carson, Perpetual Peace: What Kant Should Have Said, 14 Soc. Theory and Prac. 173, 174 (1988); Michael W. Doyle, Kant, Liberal Legacies, and Foreign Affairs (pt. 1), 12 Phil. \& Pub. Aff. 205, 225-32 (1983).

31. See Gallie, supra note 11 , at 10. 
preceded by a very important paragraph in which Kant writes that the state of peace must be founded or established; hence the need for the federation or alliance proposed in the Second Definitive Article. ${ }^{32}$

The most natural interpretation, then, is that the Definitive Articles are the foundation of perpetual peace; they contain the institutional arrangements that directly reflect the precepts of international justice. They are the ones that are designed to eliminate war from the face of the earth for all time. ${ }^{33}$

The defining characteristics of the Preliminary Articles are that they are the first steps that governments must take to end international lawlessness; those points upon which they must agree first in order to agree subsequently on the definitive and fundamental principles of international law. Here, Kant is trying to lay down the preliminary conditions conducive to definitive peace. These norms are designed to govern the intermediate status of international relations after the lawless state of nature is ended, but before the definitive law of nations is established. ${ }^{34}$ Yet, the important point to remember is that they are meant to be permanent; they are preliminary, but not provisional. Standing armies must disappear; peace treaties should not contain reservations for future wars; states should not intervene in other states' affairs; states should not be acquired by conquest; and abject means of conducting war should be permanently prohibited. The Preliminary Articles will not suffice to gnarantee peace unless the Definitive Articles are agreed upon.

\section{The Requirement That States Be Liberal Democracies}

The first principle of international ethics, embodied in the First Definitive Article, is: "The civil constitution of every nation should be republican." 35 The requirement of a republican form of government must be read in conjunction with the Second Definitive Article: "The

32. Kant writes:

The state of peace among men living in close proximity is not the natural state (status naturalis); instead, the natural state is one of war, which does not just consist in open hostilities, but also in the constant and enduring threat of them. The state of peace must therefore be established, for the suspension of hostilities does not provide the security of peace, and unless this security is pledged by one neighbor to another (which can happen only in a state of lawfulness), the latter, from whom such security has been requested, can treat the former as an enemy.

Kant, Perpetual Peace, supra note 1, at 111 (footnotes omitted).

33. The interpretation suggested by Gallie and Hinsley is not consistent with the meaning of the words "preliminary" and "definitive." See Webster's Third New International Dictionary 592, 1789 (1981). Hinsley tries to meet this objection by suggesting that the word "preliminary" is used in the sense of the law of treaties, see Hinsley, supra note 20, at 69; Gallie, supra note 11, at 9-10. Even if this is true, it does not provide or explain the contextual meaning of the word "definitive."

34. See Hinsley, supra note 20 , at 69 ; Gallie, supra note 11 , at 9-10.

35. Kant, Perpetual Peace, supra note 1, at 112. 
law of nations shall be based on a federation of free states."36 Together, these first two articles stipulate that international law should be based upon a union of republican states. ${ }^{37}$ Kant asserts that adherence to these requirements will result in an alliance of free nations that will maintain itself, prevent wars, and steadily expand. ${ }^{38}$ Contrary to the predominant belief of his time, and to conventional present legal thinking, international law and the peace it intends to secure can only be based upon a union or an alliance of participant states that protect freedom internally and whose governments are representative. Kant for the first time linked arbitrary government at home with aggressive foreign policies.

By "republican," Kant means what we would call today a liberal democracy, a form of political organization that provides full respect for human rights. ${ }^{39}$ This is so notwithstanding Kant's assertion that a pure democracy is a form of despotism. ${ }^{40}$ Kant's explanation of a republican constitution ${ }^{41}$ strongly suggests the idea of a constitutional democracy, conceived as a participatory political process constrained by respect for rights. Kant correctly points out that a system of pure democracy, if unconstrained by rights, will result in the tyranny of the majority. Kant writes:

Among the three forms of government, democracy, in the proper sense of the term, is necessarily a despotism, because it sets up an executive power in which all citizens make decisions about and, if need be, against one (who therefore does not agree); consequently, all, who are not quite all, decide, so that the general will contradicts both itself and freedom. ${ }^{42}$

Plainly, Kant wanted to set constraints upon majoritarian decisions. ${ }^{43}$ So, only a pure democracy ("in the proper sense of the term") is despotic. In contrast, the republican constitution is a form of political organization that allows people to govern themselves and to legislate by majority vote, provided that the rights of everyone are

36. Id. at 115.

37. The word "free" in the Second Definitive Article may be a reiteration of the requirement of the republican constitution: a federation of free states. See Friedrich, supra note 10 , at 45 . However, it is possible also to interpret the word "free" in that article as meaning "politically independent," thus suggesting that states enter the alliance voluntarily. See infra part III. This second interpretation is suggested by Kant's commentary to this article. See Kant, Perpetual Peace, supra note 1, at 115-18.

38. See Kant, Perpetual Peace, supra note 1, at 117-18.

39. I wish to avoid terminological debate about the meaning of the words "liberal" and "democracy." The word "liberal," as used in this Article, is broad and refers to a political theory centered around the notion of individual autonomy, individual preferences, or individual rights. A liberal democracy is one in which individual rights are honored and rulers are appointed by the people.

40. See Kant, Perpetual Peace, supra note I, at 114.

41. See infra notes $45-47,72-73,88$ and accompanying text.

42. Kant, Perpetual Peace, supra note 1 , at 114.

43. See infra notes $45-47,72-73,88$ and accompanying text. 
respected-in short, a constitutional democracy. Thus, the Kantian idea of republicanism is best understood as being in opposition to the idea of despotism, whether exercised by a minority (one person or a junta), or by the majority enforcing its decisions in violation of the rights of dissenters. ${ }^{44}$ Kant envisions the republican state as one defined by a constitution based upon three principles: freedom, due process, and equality. ${ }^{45}$

\section{A. Freedom}

The principle of freedom ${ }^{46}$ consists of the liberal principles of respect for individual autonomy and government neutrality of ends:

No one can compel me (in accordance with his belief about the welfare of others) to be happy after his fashion; instead, every person may seek happiness in the way that seems best to him, if only he does not violate the freedom of others to strive toward such similar ends as are compatible with everyone's freedom under a possible universal law . . . .47

One can hardly overemphasize the importance of this highly innovative Kantian thesis. Kant includes freedom-respect for individual autonomy under the rule of law-as the first tenet of international ethics. He is not committing the fallacy of transposing the notion of individual freedom into the conceptual framework of nationalism: freedom here is not the right to a nation-state, but primarily claims against it, claims against fellow citizens and against the government established by a social contract to implement social cooperation.

In order to understand Kant's discussion of the principle of freedom in the republican constitution, it is necessary to analyze in some detail Kant's categorical imperative. In his writings on moral philosophy, Kant attempted to demonstrate the possibility of human freedom and autonomy in the face of the deterministic laws of nature. ${ }^{48}$ Only a

44. See Kant, Perpetual Peace, supra note 1, at 114 ("government is either republican or despotic").

45. The requirements of a republican constitution, merely summarized in Perpetual Peace, are eloquently put forth in Kant, Theory and Practice, supra note 1, at 71-84.

46. See Kant, Perpetual Peace, supra note 1 , at 112.

47. Kant, Theory and Practice, supra note 1, at 72. In his Crilique of Pure Reason, Kant argues for the proposition that

[a] constitution allowing the greatest possible human freedom in accordance with laws by which the freedom of each is made to be consistent with that of all others . . . is at any rate a necessary idea, wbich must be taken as fundamental not only in first projecting a constitution but in all its laws.

Immanuel Kant, Critique of Pure Reason 312 (B373) (Norman Kemp Smith trans., 1929) [hereinafter Kant, Critique of Pure Reason].

48. Within the general framework of Kant's Critical program, the categorical imperative constitutes the solution to the third antinomy of pure reason, to wit, the apparently irresolvable conflict between the ideas of freedom and causal determinism. Kant, Critique of Pure Reason, supra note 47, at 409-15. (A445/B473-A451/B479); lmmanuel Kant, Critique of Practical Reason 3-8 (4-8) (Lewis W. Beck trans., 1956) 
free and autonomous being is capable of acting morally and can be said to have dignity and be worthy of respect. Thus Kant's primary aim in the Groundwork was "to seek out and establish the supreme principle of morality." 49 This he calls the categorical imperative, a universal law that all rational beings can make and act upon for themselves as free, self-determining agents whose actions are morally good.50 Kant offers three different formulae of the categorical imperative, yet contends that they are "at bottom merely so many formulations of precisely the same law." 51

The first formula is the most abstract. It emphasizes the impartiality and universal nature that moral principles ought to exhibit: "Act only on that maxim through which you can at the same time will that it should become a universal law."52 While initially this formula seems empty of content, there is good reason for that. Kant insists that moral philosophy must have an a priori foundation, which in turn necessarily must be formal. ${ }^{53}$ In this way, the violation of the categorical imperative is not only morally reprehensible, but irrational and self-contradictory. ${ }^{54}$ Additionally, while this maxim is formal, it is not entirely devoid of content, for it enjoins us to "act autonomously and respect the right and obligation of everyone else to do the same." 55 From the standpoint of a theory of international law, the first version of the cate-

[hereinafter Kant, Critique of Practical Reason]; Kant, Groundwork, supra note 1, at 123-29.

49. Kant, Groundwork, supra note 1, at 60 . Kant defines the categorical imperative and explicates the complex ideas contained within it in the Groundwork. In his two later works on moral philosophy, Critique of Pure Reason and The Metaphysics of Morals, Kant demonstrates the binding force of the categorical imperative on human beings who are only imperfectly rational and employs the categorical imperative to derive the whole system of human duties. It is important to note that, for Kant, the categorical imperative cannot be proved but can be deduced from pure practical reason. In the Critique of Practical Reason, Kant presents this deduction and demonstrates "the unity of practical and theoretical reason in [the] common principle" that is the categorical imperative. Kant, Groundwork, supra note 1, at 59. See Kant, Critique of Practical Reason, supra note 48 , at $43-51(42-50)$.

50. Kant, Groundwork, supra note 1, at 98-103.

51. Id. at 103. Paton identifies five interrelated but distinct formulations of the categorical imperative in the Groundwork. H.J. Paton, The Categorical Imperative: A Study in Kant's Moral Philosophy 129-30, 133-98 (1971).

52. ld. at 88.

53. See Kant, Groundwork, supra note 1, at 55; Sullivan, supra note 1, at 151-53.

54. See Kant, Groundwork, supra note 1, at 90; Sullivan, supra note 1, at 151-53. Most philosophers agree that Kant has provided a necessary condition for the validity of moral judgment. See, e.g., Marcus G. Singer, Generalization in Ethics: An Essay in the Logic of Ethics, with the Rudiments of a System of Moral Philosophy 34 (1971) (explaining that generalization is presupposed in every genuine moral judgment). However, doubt has been expressed by commentators as to whether Kant has provided a sufficient condition for such validity. Indeed, many principles which we intuitively regard as unacceptable comply with the formal requirement of this first version of the categorical imperative.

55. See Sullivan, supra note 1 , at $165-66$. 
gorical imperative provides crucial support for the universality of human rights. ${ }^{56}$

The emphasis on the agent's autonomy and the respect for the autonomy of others leads naturally to the second version, the formula of respect for the dignity of persons: "Act in such a way that you always treat humanity, whether in your own person or in the person of any other, never simply as a means, but always at the same time as an end."57 This second formula is a specification of the first in that here Kant identifies the class of moral agents: all human beings. The term "humanity" denotes the "functional complex of abilities and characteristics that enables us to set ends and make rational choices." 58 Because rationality defines the moral agent and because the categorical imperative requires universalization, we must presuppose rationality in the persons on whom the agent's behavior impinges. Kant's crucial step in the argnment is that this rationality makes persons objects that are worthy of respect, ends in themselves. Things are instrumental and have only extrinsic value. Human beings, on the other hand, have intrinsic value. In Kant's words:

Now I say that man, and in general every rational being, exists as an end in himself, not merely as means for arbitrary use by this or that will: he must in all his actions, whether they are directed to himself or to other rational beings, always be viewed at the same time as an end.59

The consequences for political philosophy of this view of respect for the dignity of human beings as the ultimate basis for the moral justification of our conduct are self-evident. If in our everyday behavior we should never consider fellow human beings merely as means, it follows a fortior that the constitution of the state, an artificial creation to serve human needs, must embody and incorporate a formula of respect for persons-a bill of human rights. ${ }^{60}$ Thus, in the Kantian vision, mechanisms for guaranteeing traditional civil and political rights, which act as barriers against the abuse of state power, form the basis of a republican constitution because such mechanisms implement the respect for autonomy and dignity of persons. ${ }^{61}$

56. For a development of this argument, see infra Part III.B.

57. Kant, Groundwork, supra note I, at 96 (footnotes omitted).

58. Sullivan, supra note 1, at 193; cf. Kant, Groundwork, supra note 1, at 105 ("So act in relation to every rational being (both to yourself and to others) that he may at the same time count in your maxim as an end in himself."). Kant here attempts to demonstrate how the second version is logically equivalent to the first.

59. Kant, Groundwork, supra note 1, at 95.

60. See supra note 47 .

61. The second version of the categorical imperative is not just a logical equivalent of the first. Rather, it adds substantive content to the formal requirements for moral judgement. Cf. John Rawls, A Theory of Justice, $251 \&$ n.29, 251-57 (1971) (arguing that one should avoid interpretation of Kant's writings as merely providing formal elements of moral theory). See generally Jeffrie G. Murphy, Kant: The Philosophy of Right 60-86 (1970) (arguing that Kant's moral point of view is not strictly formal but contains 
It would be a serious mistake, however, to conclude that the Kantian notion of freedom entails only negative duties, the duties to leave others alone to pursue their own happiness in accordance with their ideal of individual excellence. While Kant was against what he called "paternal government," 62 the second version of the categorical imperative entails positive duties as well. ${ }^{63}$ We must go beyond negative duties to make human beings our end. This command leads both to the perfection of our virtues of character and to acting benevolently toward others. ${ }^{64}$

A modern reconstruction of Kantian political theory should make room for what we would today call positive socioeconomic rights alongside the traditional negative, civil and political rights. ${ }^{65}$ Respect for the dignity of persons requires, in addition to respecting their moral space, doing our best to secure an adequate level of material well-being for every member of society. Two reasons militate in favor of requiring that socioeconomic rights be recognized by domestic and international law. First, socioeconomic rights allow individuals to flourish and fully develop their uniquely human potential. ${ }^{66}$ Second, a certain material well-being is necessary for persons fully to enjoy their civil and political rights and thus value and take advantage of liberty to its full extent. In an ideal society individuals are not only free; for them, liberty has high and roughly equal worth. 67

There are, of course, problems of priority between these two generations of rights. From the standpoint of Kantian theory, the focus should be respect for individual autonomy. Securing socioeconomic rights is necessary for individuals to flourish as autonomous persons. Indeed, a neglect of the less favored will result in a lesser possibility for many to lead meaningful and fulfilling lives in freedom. Yet, sometimes a legitimate government may enforce socioeconomic rights in such a way that it ends up thwarting, instead of stimulating, individual autonomy. The neglect of civil and political rights for the benefit of socioeconomic equality may result, as it has often done, in outright tyranny. The question of priority can be resolved by applying a Kantian

ends, purposes, and values); O. Nora Nell, Acting on Principle: An Essay on Kantian Ethics 59-93 (1975) (discussing practical application of categorical imperative). For a defense of the Rawlsian reading of Kant, see Arnold I. Davidson, Is Rawls a Kantian?, 66 Pac. Phil. Q. 48 (1985).

62. See Kant, Theory and Practice, supra note 1 , at 73.

63. See Paton, supra note 51, at 171-72; Sullivan, supra note 1, at 194 .

64. See Paton, supra note 51, at 171-72; Sullivan, supra note 1, at 194 .

65. The best modern reconstruction of Kant in this sense is, of course, Rawls, A Theory of Justice, supra note 61 , at $60-75$.

66. For an analysis of the place of socioeconomic rights in Rawlsian theory, see Frank I. Michelman, Constitutional Welfare Rights and $A$ Theory of Justice, in Reading Rawls: Critical Studies on Rawls' A Theory of Justice 319 (Norman Daniels ed., 1973) [hereinafter Reading Rawls].

67. See Norman Daniels, Equal Liberty and Unequal Worth of Liberty, in Reading Rawls, supra note 66 , at $253,256-57$. 
standard: the ideal combination of rights is the one that yields the maximum possible individual autonomy under the coercion presupposed by the social contract. This is the point of equilibrium, as it were: any move from that curve would result in a reduction of individual autonomy. 68

The third version of the categorical imperative is also highly revealing for its justification of the republican constitution and international human rights: "So act as if your maxims had to serve at the same time as a universal law (for all rational beings)."69 This formulation points to an ideal vision of a moral community, where each individual is his own judge and the members obey only laws they can rationally prescribe. ${ }^{70}$ Such a moral community describes an ideal just state and, consistently with Perpetual Peace, a world community of just states. ${ }^{71}$

\section{B. Due Process}

The second basic principle of a republican system is the derivation of all legal acts from, or dependence of all subjects on, a single common legislation. ${ }^{72}$ The legitimacy of a legal act therefore depends upon whether it is in harmony with the constitution, procedurally and substantively. ${ }^{73}$ Kant's formulation resembles the juridical definition of a state developed by Hans Kelsen. ${ }^{74}$ Kelsen's system provides a valuable counterpoint to Kant's understanding of a legitimate republican regime. For Kelsen, all legal acts must derive from a single basic norm which in turn legitimizes the first positive norm, the constitution. How-

68. These important questions of priority between positive and negative duties and between civil-political rights and socioeconomic rights are beyond the scope of this Article. However, I join Rawls in defending the priority of liberty. See Rawls, supra note 61 , at 243-51. Civil and political rights are definitive of freedom and individual autonomy, whereas socioeconomic rights, on the Kantian conception, are instrumental to freedom.

69. Kant, Groundwork, supra note 1, at 106. In the Groundwork, Kant treats the first formulation of the categorical imperative as primary, while the third version is given the position of priority in the Critique of Practical Reason. See Kant, Critique of Practical Reason, supra note 48, at 30; Paton, supra note 51, at 130 .

70. See Sullivan, supra note 1, at 214.

71. There are important differences, however, between an ethical commonwealth, in which individuals self-legislate by obedience to moral duty, and a state in which duties are imposed by statute. See Sullivan, supra note 1, at 214-18.

72. See Kant, Perpetual Peace, supra note 1, at 112; Kant, Theory and Practice, supra note 1 , at $75-77$.

73. The Kantian position is neutral toward different forms of constitutional government, the legitimacy of judicial review, and similar questions. As the diversity of solutions to these issues in actual liberal democracies shows, a republican constitution, in Kant's sense, is compatible with many different mechanisms for distributing political power within the state. For a useful survey of the different ways in which constitutionalism has been implemented, see Mauro Cappelletti, Judicial Review in the Contemporary World (1971).

74. See Hans Kelsen, General Theory of Law and State 181-92 (Anders Wedberg trans., 1946). 
ever, such derivation provides only formal legitimacy because the basic norm has no a priori, or objective, status. For Kelsen, the basic norm is "presupposed to be valid .... It is this presupposition that enables us to distinguish between individuals who are legal authorities and other individuals whom we do not regard as such, between acts of human beings which create legal norms and acts which have no such effect."75

Kant's system also mandates obedience to law that depends upon a single constitution. However, Kant's constitution, unlike Kelsen's basic norm, is not presupposed to be valid, but rather is the result of a rational choice by free agents as expressed in the legitimate social contract which requires that every citizen be a co-legislator. ${ }^{76}$ The validity of the constitution is based on the fact that it proceeds from the exercise of rational cognitive faculties by the members of the body politic. Individual members of the state will insist that the principles of the constitution comport with the categorical imperative. For Kant, the constitution ceases to be valid when it no longer reflects this aggregate rationality. Thus, allegiance to the state by individuals is based upon their rationally believing that such allegiance is right, and the fact that a rational individual will not adhere to an irrational constitution.

The requirement of a dependence of all upon a common constitution is yet another instance of Kant's strong reliance on, and reverence for, the idea of law. ${ }^{77}$ For him, an institution is justified only insofar as it has legally protected status. ${ }^{78}$ This means, domestically, that both freedom from, and subjection to, the power of the state must be legally regulated: freedom and coercion under law, or freedom and coercion according to reason. ${ }^{79}$ In a lengthy footnote, Kant explains that external lawful freedom means "the privilege not to obey any external laws [i.e., laws prescribed by someone else] except those to which I have been able to give my consent." 80 In line with the commands of the categorical imperative, ${ }^{81}$ the laws enacted by the legislature must pass the test of rational deliberation to be deserving of compliance. It follows that only in the Rechtstaat, that is, under the rule of law, is allegiance to the law rational.

Kant's political theory, however, has one weakness. His thesis of

75. 1d. at 115.

76. See Kant, Theory and Practice, supra note 1, at 75-76.

77. See, e.g., Kant, Groundwork, supra note 1, at 71 (" $[R]$ evernce is the assessment of a worth which far outweighs all the worth of what is commended by inclination, and the necessity for me to act out of pure reverence for the practical law is what constitutes duty, to which every other motive must give way because it is the condition of a will good in ilself, whose value is above all else.").

78. See Kant, Perpetual Peace, supra note 1, at 127-31; see also Gallie, supra note 11 , at 22 (explaining Kant's view that anything of value must have legally protected status).

79. See Sullivan, supra note 1, at 247-52; Waltz, supra note 15, at 331-33.

80. Kant, Perpetual Peace, supra note 1, at 112-13.

81. See supra notes $48-64$ and accompanying text. 
rational allegiance to the law is not easily reconciled with his strong opposition to a right to revolution. ${ }^{82}$ The proposition that citizens may revolt as a last resort against arbitrary power, when the sovereign has broken the agency contract, ${ }^{83}$ follows logically from any liberal political theory. ${ }^{84}$ Perhaps Kant was trying to make a purely formal point, namely that for citizens to have a legal right to revolution is self-contradictory, because there can be no higher judge to resolve the dispute between the citizens and the government. ${ }^{85}$ Nevertheless, Kant's views on civil disobedience and revolution are inconsistent with his own moral theory and with the common-sense judgments of ordinary morality. ${ }^{86}$ If government breaches the social contract, then the people may dismiss the government, by violence if all other means have failed.

The recognition of the right to resist tyranny is extremely important in international law. Beyond the consequences for the law of international human rights itself, it is significant with respect to developing a theory of humanitarian intervention. If citizens did not have a right to revolt against their tyrants, foreigners $a$ fortiori would not have a right to help them, even by noncoercive measures, in the struggle against despotism. Humanitarian intervention can be defended as a corollary to the right to revolution: victims of serious human rights deprivations, who have rationally decided to revolt against their oppressors, have a right to receive proportionate transboundary assistance, including forcible assistance. ${ }^{87}$

82. See Kant, Perpetual Peace, supra note 1, at 136; Kant, Theory and Practice, supra note 1, at 79-80; Sullivan, supra note 1, at 244-45; see also Lewis W. Beck, Kant and the Right of Revolution, 32 J. Hist. of 1deas 411, 413-15 (1971) (attempting to reconcile Kant's denial of right to revolution with his enthusiasm over French and American revolutions).

83. See infra note 100 and accompanying text.

84. See, e.g., John Locke, An Essay Concerning the True Origin, Extent, and End of Civil Government, in Social Contract 1, 122-43 (Sir Ernest Barker ed., 1962) (1690).

85. In Kant's own words:

For suppose they had such a right, and, indeed, that they opposed the actual judgment of the nation's leader, then who would determine on which side the right lies? Neither of them can serve as judge in his own case. Thus, there would have to be still another head above the head to decide between the latter and the people-and that is contradictory.

Kant, Theory and Practice, supra note 1, at 79. This is not the only reason that Kant offers to explain his belief that citizens cannot have a legal right to revolution, however. The other reasons include his obsession with the danger of reverting to the "lawless state of nature" and the prudential reason that since revolution is violent, citizens living under an unjust regime must go to the furthest extent to achieve liberal reforms peacefully. See Sullivan, supra note 1, at 244-45.

86. See Sullivan, supra note 1 , at 245 .

87. See Fernando $R$. Tesón, Humanitarian Intervention: An Inquiry into Law and Morality 5, 87-88 (1988); D'Amato, supra note 3, at 519. A growing minority of writers shares this view. See, e.g., Robert M. Chilstron, Humanitarian Intervention Under Contemporary International Law, 1 Yale J. World Pub. Ord. 93, 121-26 (1974); Anthony D'Amato, Nicaragua and International Law, 77 Am. J. Int'l L. 657, 659 (1985), reprinted in International Law: Process and Prospect 223, 225 (1987); W. Michael Reisman, Coer- 


\section{Equality}

The third principle that defines a republican system is the principle of equality of all as citizens, that is, equality before the law. ${ }^{88}$ The requirement of equality follows analytically from Kant's definition of law. Law is universal in form, ${ }^{89}$ therefore every person must have exactly the same rights as every other person. ${ }^{90}$ In Perpetual Peace, Kant reaffirms his long-standing rejection of nobility or birth as a basis for assigning rights and duties under a republican constitution.91 Despite the fact that his writings were hardly accessible to the public, Kant reveals himself, in an historical context, as a philosopher of the ordinary people. Indeed, as Sullivan argues, "Kant's entire moral philosophy can be understood as a protest against distinctions based on the far less important criteria of rank, wealth, and privilege, and perpetuated by religious and political force and fear."92 Kant's vision of society based upon a republican constitution is one that combines respect for moral autonomy and the individual, with the need for social order. It applies equally to classical laissez-faire and welfare states in the modern European tradition.

Observance of human rights is a primary requirement to join the community of civilized nations under international law. It follows that there cannot be a federation or peace alliance with tyrannical states. Domestic freedom is a primary credential required of any state before it may become a legitimate member of the international community. Yet, an important qualification is necessary here with respect to the question of democratic representation. In principle, both respect for human rights and democratic representation are needed to fulfill the requirements of the Kantian theory of international law. The main requirement of the First Definitive Article, however, is that domestic freedom be observed within each state. Because domestic freedom encompasses the right to elect the government, normally respect for human rights entails, and results in, representative government of the kind found in

cion and Self-Determination: Construing Charter Article 2(4), 78 Am. J. Int'l L. 642, 645 (1984); M. Sornarajah, Internal Colonialism and Humanitarian Intervention, $11 \mathrm{Ga}$. J. Int'l \& Comp. L. 45, 75-77 (1981). Among those opposed to the legality or wisdom of humanitarian intervention, see, e.g., Louis Henkin, The Use of Force: Law and U.S. Policy, in Right v. Might: International Law and the Use of Force 37, 41-42, 61 (1989); Oscar Schachter, In Defense of International Rules on the Use of Force, 53 U. Chi. L. Rev. 113, 117-19, 145 (1986). For a scathing critique of Henkin's article, see Anthony D'Amato, Book Review, 85 Am. J. Int'l L. 201, 202 (1991).

88. See Kant, Perpetual Peace, supra note 1, at 112; Kant, Theory and Practice, supra note 1 , at $73-75$.

89. See supra notes $52-56$ and accompanying text.

90. This is not inconsistent with the sorts of inequalities in wealth and power that arise in every society from a combination of talent, industry, and luck. See Sullivan, supra note 1 , at 256 .

91. See Kant, Perpetual Peace, supra note 1 , at 112-13 \& n.*.

92. Sullivan, supra note 1 , at 197 ; accord Kant, Perpetual Peace, supra note 1 , at 113 \& n.*. 
liberal democracies..$^{93}$ Thus, for example, we may assume that an originally unrepresentative monarchy that nevertheless respects human rights will naturally mature into a constitutional monarchy, much like those found in Western Europe today. Therefore, for the purpose of international law, the central requirement is respect for human rights. Governments that respect those rights, even if they are not representative in form, are entitled to a presumption of agency. Individuals who are free are presumed to consent to their government, much as citizens in a liberal democracy are presumed to consent to the governance of the administration brought to power through the electoral system, even if they did not vote for that government. It follows that governments that fully respect human rights are deemed to represent their citizens internationally. ${ }^{94}$

\section{The Normative Status of Nations}

Kant's understanding of the normative status of the state proceeds logically from the three criteria he proposed as the organizing principles of just republican states. The state when viewed as a unit interacting with other states does not acquire moral value greater than its components. Kant's Second Preliminary Article demonstrates that the moral standing of the state must be anchored in individual freedom. It provides that "[n]o independent nation be it large or small, may be acquired by another nation by inheritance, exchange, purchase, or gift."95 For Kant, a state is not a possession or a piece of property, and since, like a tree, the state has its own roots, "to incorporate it into another nation as a graft, denies its existence as a moral person, turns it into a thing, and thus contradicts the concept of the original contract, without which a people [Volk] has no rights."96

At first blush, Kant seems to conceive of the state in a holistic way as a moral person, with rights and duties above and beyond the individuals who make up the state. ${ }^{97}$ Such a view would regard the state as deserving respect because it is an autonomous moral being and enjoys

93. Again, a rights-constrained, as opposed to a pure, democracy is intended here by "liberal democracy." As indicated above, Kant thought that the latter was a form of despotism. See supra notes 39-44 and accompanying text.

94. This is very different from Michael Walzer's assertion that all governments are presumed to represent their people unless they render themselves guilty of genocide or similar atrocious and widespread crimes. See Michael Walzer, The Moral Standing of States, 9 Phil. \& Pub. Aff. 209 (1980).

95. Kant, Perpetual Peace, supra note 1 , at 108.

96. Id.

97. See Hinsley, supra note 20, at 66-67; see also Carson, supra note 30 , at $183-84$ (discussing Kant's idea of world federation in which states have duty to "higher authority"); Sullivan, supra note 1, at 257 (describing Kant's characterization of states as "moral persons" in Perpetual Peace). But see Tesón, supra note 87, at 53-76 (criticizing "Hegelian myth," in which states are entitled to autonomy as "moral beings" making choices). 
sovereignty in its own right. This interpretation misunderstands Kant's argnment. Kant maintains that a state is not a piece of territory, but rather a civil society created by a social contract. The state as moral person is just an analogy, except insofar as violating the state "contradicts the concept of the original contract."98 What is important for Kant, and is captured by this analogy, is that the normative value of the individual not be violated by another state. Indeed, he emphasizes several times in the same paragraph the nature of the state as a society of men and how acquisition of the state violates that association. ${ }^{99}$ The dichotomy established is between the state as a moral-political entity created by autonomous persons and the state as a mere piece of territory that can be bought and sold, not between rights of the state and rights of individuals, in which the community would hold a preeminent position at the expense of the individual. The state, for Kant, has moral standing qua the creature of a social contract.

The distinction often drawn between the horizontal and vertical contracts nicely illustrates why Kant maintains that the fundamental unit and, at the same time, fundamental end of both domestic and international law is the individual human being. The horizontal contract is the social compact entered into by citizens among themselves. The vertical contract is the agency contract between the individual beings, who comprise the state and are bound together by the horizontal contract, and their government. The vertical contract exists at the sufferance of, and for the purpose of maintaining, a healthy horizontal contract. ${ }^{100}$ If a community of individuals is founded upon a legitimate social contract-horizontal and vertical-then foreigners must respect that community and accept its rulers as the legitimate representatives of that community. This principle can be extended to hold that the reason international aggression should be condemned is that the aggressor is using citizens of the victim state as mere things; in Kant's words, "subjects are used and wasted as mere objects to be manipulated at will."101 Kant is not thinking about protecting governments unless they are legitimately appointed by their people, that is, unless there is a legitimate vertical contract. In spite of his metaphorical description of the state as a moral person, Kant is no Hegel.

Kant's international ethics follow from the categorical imperative. Just as individuals may not use human beings as mere means to an end, so foreigners, and especially foreign governments, may not use the persons that form another state by disrupting their free civil association in order to pursue the foreigners' own ends such as national glory, exer-

98. Kant, Perpetual Peace, supra note 1, at 108.

99. See id.

100. See Hannah Arendt, Crises of the Republic 85-87 (1969); see also Tesón, supra note 6, at 99-107 (arguing that "vertical contract" theory requires that government hold no autonomous rights).

101. Kant, Perpetual Peace, supra note 1, at 108. 
cise of political power, material enrichment, or the aggrandizement of territory. All communities freely constituted are deserving of respect because they come into existence as a result of the rational exercise of free choice by autonomous agents. Thus, a government is not deserving of respect per se, but only insofar as it is the agent empowered by free individuals to make the law (legislative power), apply the law (executive power), and adjudicate claims among citizens (judicial power). ${ }^{102}$ The state is the institution created to implement social cooperation grounded on the inviolability of liberty and must be honored because failure to respect the freely constituted state would be to deny the validity of the categorical imperative.

Kant's emphasis on the individual rather than the state is also apparent in his commentary to the Third Definitive Article, where Kant writes that "originally no one had a greater right to any region of the earth than anyone else." 103 Such a statement is hardly compatible with the idea of the state as the primary moral unit. For Kant, national borders are contingent features of social life. Kant never loses sight of the second version of the categorical imperative: persons should always be treated as ends in themselves, not merely as means. ${ }^{104}$ Here we have the outline of a liberal theory of self-determination-one that relies not on mystical properties of the state or the prerogatives of enlightened rulers but, properly, on the rational pursuit of freedom by autonomous agents. ${ }^{105}$

But why must states guarantee internal freedom in order to be legitimate members of the international community? One could argue that, provided international peace and stability are secured, the fundamental goal of international law according to Kant, ${ }^{106}$ the internal organization of states is irrelevant. Certainly it ought not be the indispensable starting point of a theory of international law. This argument has been repeatedly made; indeed, it is one of the tenets of the statist or realist school of thought. ${ }^{107}$ Some commentators even em-

102. See, e.g., Kant, Theory and Practice, supra note 1, at 71-84.

103. Kant, Perpetual Peace, supra note 1, at 118. Kant also suggests here, along the same lines, that all men have a "common ownership of the earth's surface." Id.

104. See supra notes 57-61 and accompanying text.

105. 1 return below to Kant's liberal defense of a world divided into separate states, as opposed to world government, see infra Part 11I.

106. See Kant, Perpetual Peace, supra note 1, at 111 ; supra notes $35-38$ and accompanying text.

I07. Statism and realism overlap but are not coextensive. Statism is the view that the basic unit of analysis is the nation-state, not the individual. Realism is the view that nation-states act in the international arena motivated by national interest. Thus, all realists are statists, but not all statists are realists. For example, the "legalists" would argue that international law conceived in a statist way is a major component of foreign policy, thus rejecting the realist emphasis on national interest. The targets of this Article are both statists, because their version of international law is morally impotent, and realists, because they tend to be moral skeptics and because their explanation of international behavior is flawed. 
brace such a reading of Kant. ${ }^{108}$ All we can aspire to, it is argued, is balance of power, or peace. Except as an occasional political tool, concern for freedom or human rights does not belong in the realm of international relations because there is no centralized authority or superstate that can guarantee the rights of subjects. ${ }^{109}$ There are of course several variations on this theme. Subtle realists would not discard the importance of human rights and democracy altogether. ${ }^{110}$ But, characteristically, realists regard such concerns as subordinate to the national interest. ${ }^{11}$ National interest is seen as an interest of the state that endures regardless of political or socioeconomic changes within the state, and extends over and above individual interests and the internal organization of the state. Conventional political theory, realists argue, addresses relations between government and governed-usually centering around individuals and their claims against the state-and is therefore incapable of accounting for the national interest as the key component of foreigu policy. Only an international theory built around the state as the primary actor can do the job. The consequence of this approach is to overlook or downplay human rights in the study, formulation, and implementation of international law and policy.

One can legitimately ask how the notion of national interest is different from the understanding reached by citizens in the horizontal social contract. Why is it that national interest persists over and above changes in the actual interests of the citizens? The idea of national interest in the realist sense is incompatible with a view of the state as a creation of men and women to serve their needs. The only enduring collective interest is the preservation of freedom; political issues are issues of how to establish a fair, efficient, and mutually beneficial system of social cooperation consistent with the protection of everyone's liberty interests. 112

The connection between freedom and international peace, however, runs even deeper than these considerations suggest. The realist challenge can be met by arguments proving that the link between peace and freedom is genuine and indisputable. Kant showed for the first

108. Classic works in the realist tradition include Hedley Bull, The Anarchical Society: A Study of Order in World Politics (1977); Kenneth N. Waltz, Man, the State, and War (1959). For an extended critical discussion of the realist view, see Marshall Cohen, Moral Skepticism and International Relations, 13 Phil. \& Pub. Aff. 299 (1984).

109. See infra notes 117-120 and accompanying text. Kant seems to make a similar argument in his discussion of the right to revolution. 1 have argued Kant's views on revolution ought to be rejected wholesale. See supra notes $82-87$ and accompanying texț.

110. See, e.g., Stanley Hoffmann, Duties Beyond Borders: On the Limits and Possibilities of Ethical International Politics 95-140 (1981).

111. See authorities cited supra note 108 .

112. It is not surprising that many of the goals that pass as national interest are, when closely examined, morally dubious: for example, territorial gains, economic gains, national glory, national unity, and ethnic pride. 
time that we cannot aspire to a lasting international peace if individual freedom is not secured within every state's borders.

\section{Freedom and Peace}

\section{A. The Empirical Argument}

Kant's work on international law begins with the premise that peace is the fundamental purpose of international law, and that under normal circumstances war is an intrinsic evil that must be avoided. Kant does not furnish separate arguments for this maxim, ${ }^{113}$ and his views on war are indeed complicated. 114 Kant believed that an international order could be established only when governments freely abjured their right to make war on each other, despite his emphasis on the necessity of coercion to sustain the law within a state. ${ }^{115}$ From the peace premise, he attempts to desigu international law so that peace will be forever secured.

Kant gives several reasons why peace is likely to be achieved when individual rights and political participation are secured. His central argument is that if people are self-governed, citizens on both sides of any dispute will be very cautious in bringing about a war whose consequences they themselves must bear. ${ }^{116}$ Those who will be eventually exposed to the horrors of the conflagration will decide whether or not to go to war. This central theme can be expanded in several directions.

In a liberal state, the government is elected and rotates periodically. These two factors are crucial restrictions on the power of the government to initiate war, both for reasons of self-interest (incumbency) and outright political and logistical limitations. In contrast, it is relatively easy for a despot to start a war. As Kant points out, the tyrant does not suffer the consequences; his privileges and prerogatives remain intact. ${ }^{117}$ Crucially, the despot does not have the benefit of objective advice and debate. He rules by force, which means that within his own entourage he is feared and vulnerable to adulation. Advisors are not likely to tell the tyrant the harsh truths, but rather only what he wants to hear. More generally, because a despotic regime does not tolerate free-

113. Kant writes that "reason absolutely condemns war as a means of determining the right and makes seeking the state of peace a matter of unmitigated duty." Kant, Perpetual Peace, supra note 1, at 116; cf. Gallie, supra note 11, at 9 (opening section of Perpetual Peace "a tour de force, without any preliminary discussion of why or in what circumstances war is an unacceptable evil"').

114. As we shall see, Kant had peculiar views, not all negative, about the role that war has played in the "Design of Nature." See infra notes 199-220 and accompanying text.

115. See Gallie, supra note 11 , at 20.

116. See Kant, Perpetual Peace, supra note 1 , at 113.

117. See id. Kant contends that the ruler does not act here as a fellow citizen, but as the nation's owner. See id. 'Kant's prudential reasons are always permeated by the theme of the categorical imperative: never use persons simply as means, which of course applies with even more strength to the government. 
dom of expression, public opinion has no significant impact on the government's decisions; consequently, there is no opportunity for public debate on the moral and prudential reasons to make war. Psychologically, insulation of tyrannical rulers from criticism and debate fuels in them a sense of megalomania. Tyrants acquire a feeling of invincibility. They become accustomed to getting away with murder (literally) internally and no doubt reach a point of self-delusion where they become convinced that they can get away with external aggression as well. ${ }^{118}$

From an institutional standpoint, the separation of powers inherent in a liberal democracy creates a system of mutual controls and relative diffusion of power that complicates and encumbers governmental decisions about war. ${ }^{119}$ No all-powerful sovereign exists who can by himself initiate hostilities. For Kant, that a multiplicity of decisionmakers will participate in decisions to make war is implicit in the notion of autonomy inherent in the republican form of government. ${ }^{120}$ The law-maker does not administer the law. Thus, liberal constitutions attempt to impose institutional limits on power, including the power to conduct foreign relations, through the checks and balances inherent in the separation of powers and through freedom of speech-notably freedom of the press. ${ }^{121}$

Another reason Kant believes that there is an increased likelihood of an enduring peace among free republics is that in a liberal democracy citizens will be educated in the principles of right, and therefore war will appear to them as the evil that every rational person knows it is. ${ }^{122}$ Kant had a rich and exciting theory of cosmopolitan education, the main theme of which is that we must cultivate universal virtues that will prevail over the bellicose instincts that we also have. ${ }^{123}$ Similar to the authors of some of the modern peace-education projects, ${ }^{124} \mathrm{Kant}$ saw clearly that peace education aimed only at inculcating fear of war

118. I suggested this explanation of the Malvinas war, see Fernando Tesón, $81 \mathrm{Am}$. J. Int'l L. 556, 558 (1987) (reviewing Crisi Falkland-Malvina e Organizzazione Internationale (Laura Forlati \& Francisco Leita eds., 1985)) ("Dictators inevitably become persuaded that they can get away with anything."). The continuing validity of this explanation to the conduct of the Iraqi ruler in the recent Gulf crisis is painfully obvious.

119. See Kant, Perpetual Peace, supra note 1, at I14; Doyle, supra note 30, at 228.

120. See supra notes $35-45$ and accompanying text.

121. See Sullivan, supra note 1, at 244.

I22. See id. at 258. Citizens in a liberal democracy would not necessarily oppose all war. Some wars waged for liberal causes will be recognized as just. See infra notes 199-220 and accompanying text.

I23. See Sullivan, supra note 1, at 287; see also Joseph M. Knippenberg, Moving Beyond Fear: Rousseau and Kant on Cosmopolitan Education, 51 J. Pol. 809, 8I5-I9 (1989) ("Kant's proposed education is avowedly 'cosmopolitan.' . . . He advocates a process aiming successfully, at four goals: discipline, the acquisition of a trade, 'cleverness,' and morality.").

124. See generally Education for Peace and Disarmament: Toward a Living World (Douglas Sloan ed., 1983) (arguing that modern peace movement ought not be "impelled solely by fear"). 
and its instrumentalities was insufficient. Fear alone is demoralizing and may lead people to surrender to a tyrant, rather than act on behalf of a morally good and peaceful world. ${ }^{125}$ A proper moral education should include instruction on the principles that underlie a just constitution from a cosmopolitan perspective, that is, on the value of human rights generally, not only as they relate to our domestic constitution. ${ }^{126}$ Because this kind of moral education emphasizes rationality as a universal trait of persons, it will induce citizens in a liberal democracy to see individuals in other nations as deserving equal respect, and thus treat them as ends in themselves, not as mere objects for the satisfaction of local preferences. ${ }^{127}$

The final reason why liberal states are likely to be peaceful is that liberal democracies foster free trade and a generous system of freedom of international movement that Kant calls the Cosmopolitan Law. ${ }^{128}$ Kant remarks that by observing a rule of hospitality for foreigners facilitating commerce with indigenous peoples, "distant parts of the world can establish with one another peaceful relations that will eventually become matters of public law, and the human race can gradually be brought closer and closer to a cosmopolitan constitution."129 Kant reaffirms this idea by observing that peoples' mutual interests unite them against violence and war, for "the spirit of trade cannot coexist with war."130

He was cognizant, of course, that "peace to do business"131 is a nonmoral reason to want peace, but that such pecuniary interests provide an additional argument for requiring a liberalization of trade and freedom of movement. Free trade and freedom of movement ${ }^{132}$ are sufficiently linked to the principles of a liberal constitution to make leaders in liberal democracies much more prone to weigh economic

125. See Knippenberg, supra note 123 , at 810 .

126. Kant maintains that cosmopolitan education is aimed at the universal good and the perfection for which humanity is destined. Immanuel Kant, Education 15 (Annette Churton trans., 1960); Knippenberg, supra note 123, at 815 .

127. Indeed, Kant thought that the moral law, the categorical imperative, was already present in a sound moral understanding and required not so much to be taught but clarified. See Kant, Groundwork, supra note 1, at 71-72.

128. See Kant, Perpetual Peace, supra note 1, at 118-19, 125; see also Doyle, supra note 30, at 231-32 ("The cosmopolitan right to hospitality permits the 'spirit of commerce' sooner or later to take hold of every nation, thus impelling states to promote peace and to try to avert war" if only out of fear of jeopardizing the benefits of trade).

129. Kant, Perpetual Peace, supra note 1, at 118; see also Kant's remarkable condemnation of colonialism, id. at 119.

130. Id. at 125.

131. "For among all those powers (or means) that belong to a nation, financial power may be the most reliable in forcing nations to pursue the noble cause of peace (though not from moral motives) ...." Id. at 125.

132. The rule of hospitality requires that "an alien not ... be treated as an enemy upon his arrival in another's country." Id. at 118. 
costs before initiating a war. ${ }^{133}$ There is no question that free trade is a strong, if not dispositive, influence over external behavior. Free trade inclines diplomacy toward peace because international business transactions require stability and predictability to be successful. Kant's views have been confirmed by the success of the European Economic Community and even by the global system of international trade regulated by GATT and similar institutions. It is not by coincidence that the European Economic Community requires democracy as a prerequisite for membership, as does the more recent Mercosur, the Argentine-Brazilian free market agreement. ${ }^{134}$

Recent research by Michael Doyle and R.J. Rummel bolsters Kant's argument for the causal link between domestic freedom and peace. ${ }^{135}$ These modern versions of Kant's argument have shown that Kant's prediction of a gradual expansion of the liberal alliance has been confirmed by events of the last 200 years, and notably the last 45 years. These authors' research has demonstrated that Kant was essentially right. Events since the publication of these articles provide splendid supplementary confirmation of the Kantian thesis. ${ }^{136}$

Liberal states have shown a definite tendency to maintain peace among themselves, while nonliberal states have shown themselves to be generally prone to make war. The historical data since 1795 seems to indicate that even though liberal states have become involved in numerous wars with nonliberal states, liberal states have yet to engage in war with one another. ${ }^{137}$

Doyle concedes that liberal states have behaved aggressively toward nonliberal states, but he attributes this fact precisely to the difference in regimes. ${ }^{138}$ Conversely, nonliberal states have frequently behaved aggressively among themselves. Therefore, only a community of liberal states has a chance of securing peace, as Kant thought. Should people ever fulfill the hope of creating such a liberal international community, the likelihood of war will be greatly reduced.

Alternative hypotheses have not been forthcoming to explain the

133. One could expand this theme by saying that liberal citizens tend to be more cosmopolitan and less nationalistic, except concerning the defense of freedom, precisely because they place the individual at the origin and end of political arrangements.

134. For the European Economic Community, see 1978 Bull. Euf. Communities, No. 3, at 5-6; for the Argentine-Brazilian free trade agreement, see Shirley Christian, Argentina and Brazil Sign Pacts, N.Y. Times, July 31, 1986, at D18.

135. See Doyle, supra note 30, at 213; Michael W. Doyle, Kant, Liberal Legacies, and Foreign Affairs (pt. 2), 12 Phil. \& Pub. Aff. 323 (1983) [hereinafter Doyle, Liberal Legacies (pt. 2)]; Michael W. Doyle, Liberalism and World Politics, 80 Am. Pol. Sci. Rev. 1151,1162 (1986) (reprinted in substantially the same form as Michael W. Doyle, Liberal Institutions and International Ethics, in Political Realism and International Morality 185, 190-91 (Kenneth Kipnis \& Diana T. Meyers eds.; 1987)); R.J. Rummel, Libertarianism and International Violence, $27 \mathrm{~J}$. Conflict Resol. 27 (1983).

136. See supra note 2.

137. See Doyle, supra note 30 , at 209-17.

138. See Doyle, Liberal Legacies (pt. 2), supra note 135, passim. 
liberal peace. I have not seen serious challenge to the evidence provided by Doyle and Rummel. Doyle's assertion that constitutionally secure liberal states have never engaged in war with one another is indeed bold. ${ }^{139}$ Writers who take issue with this view contest only the thesis-held by Rummel but not by Doyle-that liberal democracies are generally peace-prone, regardless of the nature of the other regimes. ${ }^{140}$ Nevertheless, everyone concurs in the factual assertion that democratic states rarely go to war amongst one another. ${ }^{141}$ To be sure, there are some difficult cases. ${ }^{142}$ Yet, even if those cases are treated as genuine instances of war between liberal states, the correlation is still so strong that it begs explanation. The argument is not that war between liberal states is impossible, but that it is highly unlikely. Kant warns that there will be regressive wars and setbacks in the establishment of the liberal alliance. Nevertheless he was confident that the alliance would expand and solidify with time. ${ }^{143}$

Some commentators have challenged the plausibility of the causal connection between freedom and war. They have treated the correlation as spurious, either the result of pure coincidence or, more likely, of an underlying common factor unrelated to the nature of the domestic regimes. Professor Diana Meyers has taken such a position: while she agrees that liberal states by and large have maintained peaceful relations, she raises questions about the explanation offered by Kant and Doyle. ${ }^{144}$ Meyers offers two considerations to deny the premise that liberal democracies provide mechanisms through which aggregated self-interest is translated into national policy. ${ }^{145}$ First, state bureaucra-

139. See Doyle, supra note 30, at 213.

140. See Chan, Mirror, Mirror on the Wall: Are the Freer Countries More Pacific?, 7 Peace Res. Soc'y Papers 31 (1984); Melvin Small \& J. David Singer, The War Proneness of Democratic Régimes, 1816-1965, 1 Jerusalem J. Int'l Rel. 50 (1976); Erich Weede, Democracy and War Involvement, $28 \mathrm{~J}$. Conflict Resol. 649 (1984). As indicated above, Doyle concedes, and the evidence seems to show, that liberal states behave ag. gressively toward nonliberal states.

141. See David Garnham, War-Proneness, War-Weariness, and Régime Type: 1916-1980, 23 J. Peace Res. 279, 283-84 (1986); authorities cited supra note 140. For another challenge to Rummel's methodology, see Jack Vincent, Freedom and International Conflict: Another Look, 31 Int'l Stud. Q. 103, 103-05, 111-12 (1987). But see R.J. Rummel, On Vincent's View of Freedom and International Conflict, 31 lnt'l Stud. Q. 113,113-17 (1987).

142. Two hard cases are the 1812 war between England and the United States, and the First World War. As to the first, arguably the United States became a liberal republic only after 1865; as to the second, Doyle's explanation is that lmperial Germany, although largely a liberal republic for domestic issues, did not allow any popular participation in foreign affairs decisions. See Doyle, supra note 30, at 216-17, n.8.

143. See Kant, Perpetual Peace, supra note 1, at 118.

144. See Diana T. Meyers, Kant's Liberal Alliance: A Permanent Peace?, in Political Realism and International Morality, supra note 135, at 212, 219.

145. Id. at 215. Similarly, Professor Hinsley opines that "[i]t is impossible to overlook the lameness of th[e] conclusion" that republican forms of government are more likely to lead to international peace. Hinsley downplays Kant's emphasis on internal 
cies often distort public opinion, and thus "liberal democracy does not in any straightforward way place state action under the control of majority interests." 146 Second, people are deceived about their self-interest, and therefore express preferences that may militate for or against peace. ${ }^{147}$ Public opinion in a liberal democracy, it is argued, may also be bellicose. Neither a free press nor a constitutional system with checks and balances has prevented leaders of liberal democracies from waging aggressive wars for spurious liberal causes. ${ }^{148}$

This reply to Kant and Doyle is unconvincing. The general skeptical position that liberal democracies do not provide a true outlet to majority opinions and preferences proves too much. To accept the argument one must believe that there is no real difference, in any respect-not just in the formulation of foreign policy or the initiation of wars- between liberal democracies and despotisms. While threats to popular participation posed by bureaucracies should be a matter of concern, this does not equate all political systems in terms of the degree to which popular will is expressed. Liberal democracies provide better mechanisms for political participation, to put it mildly, than do tyrannies. While there are surely hard cases, free political systems and despotic ones can be distinguished. We draw the distinction precisely in terms of how human rights are protected, how the citizen's interests are served, and the degree of their participation in the political process.

More importantly, this objection misses Kant's central point: peace is likely to be maintained only among liberal societies and, consequently, the likelihood of world peace will increase as the liberal alliance expands. All the examples of liberal aggression involve confrontations against nonliberal states. ${ }^{149}$ Yet, the Kantian theory insists that the difference in regimes is the cause of instability. Liberal states do engage in aggressive behavior against nonliberal states, but this fact cannot support the claim that official duplicity could serve just as well to rationalize an attack on a bothersome liberal state. ${ }^{150}$

The argument seems to be that the psychology of power is the same regardless of which political system is in place and, therefore, both tyrannical and democratic rulers are equally prone to deceiving the people and waging war for dishonorable reasons such as the ruler's self-aggrandizement. However, the Kantian hypothesis is precisely that

freedom and emphasizes instead the freedom of the state and the "design of Nature" as Kant's main causes of peace. See Hinsley, supra note 20, at 71. Professor Hinsley's view on this point is empirically implausible and unfaithful to Perpetual Peace and to Kant's philosophy generally.

146. Meyers, supra note 144, at 215.

147. See id.

148. See id. at 216 (using the Vietnam War as an example).

149. Plausible candidates are the force used in Vietnam, Grenada, and Panama by the United States, and in Chad and Congo by France and Belgium, and in Pakistan by India.

150. See Myers, supra note 144, at 216. 
in a liberal democracy there are intrinsic limitations on the ability and discretion of governments to deceive and manipulate. It is not enough to say that democratic governments are also capable of deceit and manipulation; the very point of democratic institutions is to keep political power, with all its corrupting potential, under check. ${ }^{151}$ While the psychology of power may be the same across political systems, there is little question that in liberal societies institutional constraints are more likely to prevent bad governments from doing too much damage, both at home and abroad.

Other commentators have accepted the evidence, but have nevertheless attempted to explain the liberal peace by different hypotheses. The realist school of thought in international relations has long maintained that war is caused by prudential reasons that affect all state actors equally in the international arena. These reasons are not related to the difference in regimes. Doyle summarizes the realist theory of war:

Specific wars ... arise from fear as a state seeking to avoid a surprise attack decides to attack first; from competitive emulation as states lacking an imposed international hierarchy of prestige struggle to establish their place; and from straightforward conflicts of interest that escalate into war because there is no global sovereign to prevent states from adopting that ultimate form of conflict resolution. 152

Thus, the realist explains peace through purely prudential factors that motivate state decision-makers. Realists downplay the importance of the difference in domestic regimes and emphasize features of states and governments that derive from the condition of international anarchy. ${ }^{153}$

151. There are countless real and counterfactual examples to illustrate the Kantian hypothesis. My favorite one is: there would have been no Malvinas war between the United Kingdom and Argentina had there been a democratic government installed in Buenos Aires. . While there is no indication that irredentist sentiments have subsided in Argentina, the two countries, with Argentina now a member of the liberal alliance, are pursuing peaceful means to solve the conflict. See, e.g., the UK-Argentine Joint Statement on Relations and a Formula on Sovereignty with Regard to Falkland Islands, South Georgia, and South Sandwich Islands, 29 I.L.M. 1291 (Sept. 1990); see also BBC Summary of World Broadcasts, The Monitoring Report, Part 4 (Dec. 29, 1990) (Argentine Foreign Minister downplaying British Prime Minister's comparison of Iraqi invasion of Kuwait with 1982 Argentine invasion of Malvinas).

152. Doyle, supra note 30, at 219. As Doyle notes, this tradition goes back to Thucydides and Hobbes. See id.; authorities cited supra note 108. Other realist explanations of the liberal peace discussed and rejected by Doyle are based on hegemony or equilibrium, along the lines suggested by Raymond Aron. In refuting Aron, Doyle notes that the liberal peace persisted in the inter-war period when there was no hegemony. Doyle, supra note 30, at 223. Doyle also points out that hegemonic control is overestimated in both the pre-war and post-war periods. It is argued that in a situation of international equilibrium aggressive attempts at hegemony will deter wars. However, bipolar equilibrium is insufficient because it only explains peace among the polar powers, not proxy or regional wars. See id. at 224.

153. See id. 
Realists have failed. to explain the undeniable peace that has reigned among liberal states for so long. To suggest that relations among states with similar domestic regimes, liberal or not, would be peaceful, conflicts with the evidence regarding relations among feudal, communist, and fascist societies. ${ }^{154}$ To say that the liberal peace only reflects the absence of deep conflicts of interest among liberal states simply begs the question of why liberal states have fewer or less fundamental conflicts of interest with other liberal states than liberal states have with nonliberal states, or nonliberal states have among themselves. ${ }^{155}$

But let us concede, gratia argumentandi, that the real reason for peace is the similarity in regimes, so that a community of despotic states could equally maintain peace. In that case, since peace is our ultimate goal and since uniformity of regimes is the only guarantee for peace, we have a choice of designing a system of international law that would either require respect for human rights or require despotism. On any defensible theory of morality, if that is our choice, we would prefer an international legal system that required states to secure human rights and political representation and thus be uniform on the side of liberty.

There is a strong factual correlation between internal freedom and external peaceful behavior toward similarly free societies; the causal dynamics that underlie the correlation seem very plausible; and those who disagree with this explanation have failed to provide convincing alternative explanatory hypotheses. The conjecture that internal freedom is causally related to peaceful international behavior is as safe a generalization as one can make in the realm of political science. Kant's empirical argument therefore shows that, if only for prudential reasons, international law must require full respect for human rights.

\section{B. The Normative Argument}

The second Kantian argument for including a requirement of respect for human rights as a foundational principle of international law is even more straightforward: Governments should be required by international law to observe human rights because that is the right thing to do. Because international law is rooted in the categorical imperative, it must likewise require respect for human rights if it is to be universal.

Kant commentators have overlooked the fact that Kant expressly offers this argument along with the empirical one. In Perpetual Peace, Kant defends the universal requirement of human rights and democracy as grounded in "the purity of its origin, a purity whose source is the pure concept of right." 156 The empirical argument is then offered in addition to this normative one. Writers who felt uncomfortable with Kant's

154. See id. at 22.

155. See id. at 224.

156. Kant, Perpetual Peace, supra note 1, at 113 (emphasis added). 
First Definitive Article have attacked the plausibility of the empirical argument, ${ }^{157}$ without realizing that it was just a reason given to reinforce the main argument, which alone suffices: that a global requirement of a republican constitution logically follows from the categorical imperative. ${ }^{158}$ Thus, Kant's complete argument for democracy and human rights as a requirement of international law is far stronger than many of his critics thought. The normative argument is addressed to those who rank justice over peace; the empirical argument, to those who rank peace over justice.

Protecting human rights is the reason why governments exist in the first place. ${ }^{159}$ The reasons that support internal freedom are universal, they derive from the categorical imperative, therefore, they should be embodied in the law of nations which also purports to be universal. Because Kantianism relies on rationality as a universal trait of persons, it is incompatible with relativism. It is not possible to defend simultaneously Kant's theory of human nature and morality, and the view that liberal democracy and respect for persons is good only for certain societies. The categorical imperative is universal and holds for every civil society regardless of history and culture. Liberal democracies, ranging from laissez-faire states to welfare states, are the only ones that are likely to secure individual freedom, thereby allowing human beings to develop their potential fully. Therefore, the only way in which international law can be made fully compatible with the freedom of individuals to pursue and act upon rational life plans is if it contains a strong obligation for governments to respect human rights. International law must be congruent with individual autonomy; the trait, for Kant, that sets human beings apart from other species.

Kant insists that pure ethics, or pure duty, be separated from historical and cultural contingencies. The whole enterprise of moral philosophy, for Kant, is based on that part of practical knowledge that is pure, perceived by human beings a priori, that is, independent of their experiences and traditions. ${ }^{160}$ The nonrelative character of Kantian philosophy is easy to see in the realm of individual or personal morality. Indeed, the examples that Kant gives are of this type. ${ }^{161}$ Yet, there is every reason to extend Kant's moral universalism to political morality as well. The contingent division of the world into discrete nation-states

157. See, e.g., Hinsley, supra note 20 , at 71 .

158. See Kant, Perpetual Peace, supra note 1, at 112-15; Kant, Universal History, supra note 1 , at $34-36$. In addition, Kant's general moral theory logically leads to the proposition, see authorities cited supra note 1 .

159. See Tesón, supra note 6, at 99-120.

160. See Kant, Groundwork, supra note 1, at 55-56. Kant asks: "Do we not think it a matter of the utmost necessity to work out for once a pure moral philosophy completely cleansed of everything that can only be empirical and appropriate to anthropology?" 1d. at 57.

161. See id. at 84-86. 
does not transform political freedom ${ }^{162}$ from an ethical imperative into a mere accident of history. Just as rational, albeit fallible, beings are capable of selecting the morally correct action out of a pure sense of duty, so too are the same rational beings creating the law of nations capable of selecting the morally correct form of political organization.

International law is concerned, at least in part, with the incorporation of those rules and principles that are deemed just on a global scale. First among them is the principle of a republican constitution proposed by Kant. This is not generated by a desire to impose an idiosyncratic system of values upon groups in other parts of the globe who have different traditions. The republican constitution of the liberal-democratic society, far from being idiosyncratic, is objectively right; it is not tied to empirical circumstance or historical accident. The republican constitution derives from the categorical imperative, from the exercise of rational faculties by autonomous agents capable of articulating the pure concept of right, as Kant expressly says in Perpetual Peace on this very issue. ${ }^{163}$ To be consistent with justice, therefore, international law must require that states respect human rights. An international legal system that authorizes individuals to exercise despotic political power is morally deficient in a fundamental way. It disregards ethics that are central to Kant's "kingdom of ends," 164 in which humans are defined by their aptitude to become members of the same moral community, worthy of dignity and respect. ${ }^{165}$ Such is the notion that the international law of human rights attempts to vindicate. ${ }^{166}$ In the Kantian vision, human rights are not mere privileges graciously granted by individuals in power-for example, by signing an international human rights convention. They are constitutive of the international definition of a legitimate nation-state.

The Kantian normative argument for the primacy of human rights can be reconstructed or extended using modern social contract theory. ${ }^{167}$ The just civic constitution is the one that would be agreed upon by parties in an original position of uncertainty. The just world order likewise is the one that would be agreed upon by rational individuals in an original position of uncertainty, that is, knowing neither which country they will be part of nor what socioeconomic position they will occupy in that country. Under this model, and contrary to what John

162. See supra part 11.A.

163. See supra notes 38-46 and accompanying text.

164. See supra notes 69-71 and accompanying text.

165. See Kant, Groundwork, supra note 1, at 95-96.

166. State-oriented international lawyers persistently disregard the fact that the respect for human dignity was a major concern of the international community after 1945 . See, e.g., U.N. Charter pmbl.

167. See Rawls, supra note 61, at 11-17 (developing modern Kantian-contractarian theory). The passage that follows summarizes the arguments made in Tesón, supra note 6 , at 109-20, and in Tesón, supra note 87, at 58-71. 
Rawls himself has suggested, ${ }^{168}$ the parties in the original position are individuals, not governments. They will agree on, among other principles of global justice, an international bill of human rights and on strong mechanisms to protect them against their governments, such as international human rights courts and even humanitarian intervention in cases of extreme human rights deprivations. They will include the notion of just constitutions as the fundamental requirement for a just world order. The contractors, however, will agree on a world of separate nations, thus stopping short of creating a global super-state, for reasons discussed below. ${ }^{169}$ The original contractors will not risk their liberty interests by gambling on a law of nations that would permit governments to adopt tyrannical methods, because they might end up as citizens of tyrannical states. ${ }^{170}$ Thus, the very principles of rational choice suggested by Rawls exclude a purely statist conception of international law.

\section{The Problem of Authority and Enforcement}

Kant's Second Definitive Article provides that international law must be based on a federation of free states. Kant refers first to international law. We have seen already how important the idea of law is for Kant. ${ }^{171}$ Domestically, civil society, the just civic constitution, results, as in Hobbes and Locke, from citizens surrendering their unlimited freedom in the state of nature in order to create the rule of law, the Rechtstaat, which alone can rationally secure individual freedom. The moral and civilized nature in us thus overcomes our evil instincts of lawlessness and destruction. We accept coercion and the idea of law and order to secure freedom for all. ${ }^{172}$ Only then can we pursue the higher forms of life which define our essential humanity.

The human propensity to master our evil nature with reason ${ }^{173}$ and reliance on law holds internationally as well. Goveruments, even in times of Kant's international state of nature, want to see their actions, no matter how self-interested and destructive, as legally justified. Far from reaching a skeptical conclusion from this crude reality of world

168. See Rawls, supra note 61 , at 378 .

169. See infra notes 182-197 and accompanying text.

170. See Tesón, supra note 6 , at $109-20$; Tesón, supra note 87 , at $58-71$; see also Mark R. Wicclair, Rawls and the Principle of Nonintervention, in John Rawls, Theory of Social Justice 289, 299-301 (H. Gene Blocker \& Elizabeth H. Smith eds., 1980) (parties to contract in original position would choose limited intervention rule over nonintervention rule).

171. See supra notes $77-81$ and accompanying text.

172. See Kant, Perpetual Peace, supra note 1, at 111-12 \& n. $\dagger$ ("For by entering into civil society, each person gives every other . . . the requisite security.").

173. See Gallie, supra note 11 , at 16 ("The intensity of feeling which Kant focused upon this hope for Reason in human life is unparalleled in the history of political thought, anyhow since Plato."). 
politics, Kant saw this reliance on legal discourse as evidence of rationality:

The homage that every nation pays (at least in words) to the concept of [law] proves ... that there is in man a still greater, though presently dormant moral aptitude to master the evil principle in himself (a principle he cannot deny) and to hope that others will also overcome it. ${ }^{174}$

Therefore, according to Kant, the international order logically ought to mirror the domestic order; just as individuals would choose to create a civic constitution to solve the problems posed by the ruthless state of nature, so too would the same individuals, organized in nationstates, agree upon a system of international law to solve the problems posed by the international state of nature.

The analogy to domestic ordering raises the question of whether a successful system of international law must also be centralized into a super-state with a world government. This question is, of course, an old acquaintance of international lawyers: the view that there cannot be international law without an international sovereign has long since been discredited in international legal circles. ${ }^{175}$ In addition, the controversy over whether international law is "really" law seems to be primarily semantic. ${ }^{176}$ Yet, the objection is still worth examining, for it could well be that critical philosophical reflection will lead us to reconsider world government as a better alternative. ${ }^{177}$

In order fully to understand Kant's proposed solution to this dilemma, one must remember that Kant was writing at a time when war was the main method of settling international disputes and when the right of princes to make war was not seriously in dispute. ${ }^{178}$ Politicians, scholars, and other educated persons living in that climate of interna-

174. Kant, Perpetual Peace, supra note 1, at 116. The word "law" has been substituted for "right" in this Article; see supra note 18.

175. See, e.g., Anthony D'Amato, International Law: Process and Prospect 1-26 (1987) (rejecting idea that international law must he centrally enforced to be considered law); W. Michael Reisman, Sanctions and Enforcement, in International Law Essays 381, 386 (Myres S. McDougal ed., 1981) (discussing community and group sanctions as distinguished from state-imposed); see also Eiichi Fukatsu, Coercion and the Theory of Sanctions in International Law, in The Structure and Process of International Law 1187 (R. St.J. Macdonald \& Douglas M. Johnston eds., 1983) (discussing diplomatic, economic, and military coercion by individual state as international law sanctions).

176. See Glanville L. Williams, International Law and the Controversy Concerning the Word "Law," 22 Brit. Y.B. Int'l L. 146, 158-62 (1945).

177. See Carson, supra note 30 at 184-91 (arguing that "ultra-minimal" world government could preserve world peace).

178. For an account of international law allowing the right of states to wage war prior to the United Nations Charter, see 2 L. Oppenheim, International Law 177-78 (H. Lauterpacht ed., 7th ed. 1952); see also Hubert Thierry et al., Droit International Public 538-41 (1975) (discussing development of ideas of pacifism and just war from early Christianity to absolute monarchies of the 18 th century). Kant has numerous references in his writings to international lawlessness and the interuational state of nature. See, e.g., Kant, Perpetual Peace, supra note 1, at 115-16; Kant, Theory and Practice, supra 
tional lawlessness were his audience. Therefore, the idea of an international legal system that would outlaw war was revolutionary. Of course, today the presumption is against the right to make war, not in favor of it, and so many of Kant's arguments and assumptions might seem to us outmoded or taken for granted.

Both Hobbes and Rousseau faced the problem of authority before Kant. Hobbes, of course, thought that international relations were the state of nature par excellence. ${ }^{179}$ Some commentators of Kant's work followed his argument to its seemingly logical conclusion: they read "federation" in the modern sense, as meaning a federated republic with a unified sovereigu. ${ }^{180}$ These commentators mistakenly argued that just as a constitutional government is the answer to the problems of social cooperation, freedom, and order within civil society; so too, world government should be the answer to similar problems internationally. Others believed that world government is what Kant should have argued for and that anything less is either useless, because it does not solve the problem of the international state of nature, or logically inconsistent with Kant's own arguments in Perpetual Peace and elsewhere. ${ }^{181}$

Most modern commentators, however, agree that Kant did not support world government. ${ }^{182}$ Not only does Kant expressly disavow the creation of a centralized world government, ${ }^{183}$ but the Third Definitive Article, establishing the Cosmopolitan Law, or the rules of free trade and universal hospitality, is inexplicable outside the context of a world of independent nation-states. ${ }^{184}$

Kant's answer (or, rather, the best Kantian answer) to this problem is to propose instead an alliance of separate free nations, united by their moral commitment to individual freedom, by their allegiance to the international rule of law, and by the mutual advantages derived from peaceful intercourse. The global distribution of authority proposed by Kant is thus quite close to the modern international legal system: states have rights and duties under international law, because they represent autonomous moral beings. However, there is no sovereign to enforce them; enforcement is

note 1, at 67; see also Waltz, supra note 15, at 334 (discussing Kant's conception of states in international system).

179. See Thomas Hobbes, On Dominion, ch. XIII, cited by Hinsley, supra note 20, at 51. The problem of authority confounded Rousseau. Consequently his works contain some inconsistencies about the appropriate resolution. See Hinsley, supra note 20, at 46-51 (discussing Rousseau's works on international relations).

180. See, e.g., Friedrich, supra note 10, at 45 .

181. See Carson, supra note 30 , at $179-84$.

182. See Hinsley, supra note 20, at 62-70; Gallie, supra note 11, at 20-21; Waltz, supra note 15, at 335-37; Jean-Michel Besnier, Le Droit International Chez Kant et Hegel, 32 Archives De Philosophie Du Droit: Le Droit International 85, 91 (1987).

183. See Kant, Perpetual Peace, supra note 1, at 117.

184. See id., at 118-19. 
decentralized. ${ }^{185}$ Kant was ahead of modern international law in requiring that states observe human rights as a precondition for joining the alliance.

Quite apart from textual evidence, and notwithstanding the serious problem of the lack of centralized enforcement, there are good reasons to prefer a loose organization of separate states subject to international law to a centralized world government. Kant defended separate states not only because he thought that in this way his proposal would be more realistic, but because he thought that such a loose system was morally justified. ${ }^{186}$

First, he decided that world government presents too great a threat to individual freedom. Liberty is better secured when political power is relatively diluted. Kant wrote:

[A world consisting of separate nations] is rationally preferable to [its] being overrun by a superior power that melds them into a universal monarchy. For laws invariably lose their impact with the expansion of their domain of governance, and after it has uprooted the soul of good a soulless despotism finally degenerates into anarchy. ${ }^{187}$

Kant was aware that while world government may be an attractive idea in theory, it carries the danger of degenerating first into a world tyranny and ultimately back into international anarchy. ${ }^{188}$ Under a centralized world government, resisting the tyranny of a corrupt leadership would present an overwhelming logistical problem for individuals struggling to reestablish human rights and representative democracy. Freedom fighters would not have safe refuge, nor the fiscal and political support of independent representative governments. Nor would free states exist to moderate the excesses of despots through diplomacy and coercive intervention when appropriate. ${ }^{189}$

Second, a system of separate states allows individuals to associate with those that share their same culture, customs, history, and language. Such a system is more likely to respect the individuals' "community" interests and contribute to the affirmation of their self-respect that ultimately leads to the flourishing of individual autonomy. From a practical standpoint, a decentralized system minimizes conflicts originating as a result of those cultural differences.

Kant supports his view with a curious argument, mixing a Hobbes-

185. See infra notes 187-197 and accompanying text.

186. See Hinsley, supra note 20, at 63 .

187. Kant, Perpetual Peace, supra note 1, at 125.

188. After suggesting the possibility that nations might consider world government, Kant writes: "But they do not will to do this because it does not conform to their idea of the [law] of nations, and consequently they discard in hypothesis what is true in thesis." ld. at 117; see also Gallie, supra note 11, at 23-24 (discussing Kant's rejection of both peace-by-empire and peace-by-federation).

189. See Terry Nardin, Law, Morality, and The Relations of States 238-39 (1983). 
ian perspective with a sort of evolutionary determinism. ${ }^{190} \mathrm{He}$ argues that nature has used war as an instrument to force people to live in all sections of the globe, and eventually to reach the situation of separate nations in a state of (potential) war. On the other hand, nature has used the same features that divide peoples-differences in language and religion-to create an "equilibrium of the liveliest competing powers" which alone can control the danger of the deceptive peace that despotism brings-as he writes, "in the graveyard of freedom."191 Despite Kant's dubious deterministic parlance, ${ }^{192}$ the argument is based on Kant's original theory of the "asocial sociability" of human beings. ${ }^{193}$

In the international arena, the Kantian analysis shows how decentralized enforcement can take the place of a world police force, and underscores the subtlety of interuational mechanisms to secure compliance. ${ }^{194}$ Of course, the idea that communities with a strong sense of cultural identity should be allowed to be autonomous is a relative assessment. It springs from the empirical conjecture that if subject to world government, different groups and minorities would tend to see their claims for identity ignored by a huge bureaucracy, whereas local government might appear to be more responsive to such claims. Yet by no means must all cultures live under separate governments; there are a number of successful examples of multicultural states. Furthermore, cultural differences' should not preclude nations from voluntarily merging into larger political units, such as the European Economic Community. Finally, principles of respect for individual human rights trump the right to self-determination. ${ }^{195}$

190. See Kant, Perpetual Peace, supra note 1, at 120-25.

191. Id. at 125.

192. Why should the champion of free will talk about the Laws of Nature forcing people to do things? Professor Besnier rightly criticizes Kant's abuse of the notion of the Design of Nature. See Besnier, supra note 182, at 93-94 (calling the argument "la ruse de la nature"); see also Robert K. Faulkner, Liberal Plans for the World: Locke, Kant, and World Ecology Theories, Int'l J. World Peace, March 1990, at 61, 77-79 (1990) (critiquing Kant's "strangely ruthless humanitarianism" that assumes war will eventually dictate progress toward a rational world).

193. See George Modelski, Is World Politics Evolutionary Learning?, 44 lnt'l Org. 1, 2-6 (1990) (Kant's historicist argument confirmed by recent studies on nature of international cooperation); Hinsley, supra note 20, at 72 (Kant's international philosophy combined "the historical sense, the moral element in politics, and the irrational element in man"); Gallie, supra note 11, at 28-29 (for Kant, idea of human reason excludes use of war); see also Sullivan, supra note 1, at 235-41 (summarizing Kant's philosophy of history).

194. Gallie eloquently summarizes the Kantian tension between man's rational powers: Reason is "that tendency, in all human thought and conscious effort, towards, at one and the same time, ever greater unity, system and necessity, and equally towards ever sharper and more constant self-criticism and self-control." Gallie, supra note 11, at 14.

195. The question of the interplay between self-determination and individual human rights is an extremely complex one, and is beyond the scope of this Article. See 
Kant argues for the maintenance of separate nation-states as a balance between the dangers to freedom posed by centralized world government and the state of nature. ${ }^{196}$ An alliance of liberal democracies subject to international law will provide the exact point of equilibrium for world order. Compliance will hopefully be achieved gradually by operation of subtle decentralized systemic mechanisms. ${ }^{197}$

If a morally justified international law is the result of such a liberal alliance, the question arises as to the legal status of those states that are not liberal democracies. First, tyrannical governments are outlaws. However, they are not outside the law of nations. Like domestic criminals, they are still bound by elementary principles, such as the rules that prohibit crimes of aggression and war crimes. While outlaw governments do not benefit from the rights conferred by membership in the alliance, they retain some rights. For example, if they are accused of human rights violations or war crimes, they have a right to be tried by an independent and impartial tribunal in accordance with wellestablished international rules. ${ }^{198}$

Second, a liberal theory of international law seeks to protect individuals. Therefore, actions, even by legitimate governments, that violate the rights of individuals in tyrannical states are prohibited. Citizens in undemocratic states lack representation, but they have not lost their rights. It follows that agreements creating obligations that benefit individuals should be respected. Such agreements include conventions inspired by elementary considerations of humanity and, in some cases, treaties that establish boundaries. However, agreements that dictators enter into to benefit themselves are binding neither upon members of the alliance nor upon the citizens of the tyrannical state. Because dictators do not represent their people, they cannot create obligations for their subjects. Such agreements are not respected because of the traditional principle pacta sunt servanda, but rather for prudential reasons or because they protect oppressed individuals.

Similarly, a liberal theory of international law must account for the role of force and war. Force may be u'sed in defense of persons and, derivatively, in defense of representative governments and states. ${ }^{199}$ Because members of the liberal alliance are in compliance with the First

Avishai Margalis \& Joseph Raz, National Self-Determination, 87 J. Phil. 439, 454-61 (1990).

196. According to Kant, the state of nature exists when states are at war or a threat of war exists. See Kant, Perpetual Peace, supra note 1, at 111. Yet, the establishment of the liberal alliance, while a dramatic improvement, will still harbor dangers of war against nonmembers, i.e., despotic states. See infra text accompanying notes 199-220. Perpetual peace will be finally achieved when all nations become democratic and join the alliance.

197. See supra note 175 .

198. See, e.g., European Convention for the Protection of Human Rights and Fundamental Freedoms, art. 6, 213 U.N.T.S. 221, 228 (1955).

199. See Tesón, supra note 87, at 111-23 (arguing that intervention is appropriate only if (1) force is used to thwart human rights violations, (2) nonhumanitarian motives 
Definitive Article, force will never need to be used to exact compliance with their international obligations. However, force will sometimes have to be used against nonliberal regimes as a last resort in self-defense or in defense of human rights. Liberal democracies must seek peace and use all possible alternatives to preserve it. In extreme circumstances, however, violence may be the only means to uphold the law and to defend the liberal alliance against outlaw dictators that remain nonmembers. Such, I believe, is the proper place of war in the Kantian theory.

However, Kant seems to disagree. In his commentary to the Sixth Preliminary Article, Kant dismisses the idea that there could be a just war. War, Kant writes, is "a sad necessity in the state of nature [where] the outcome of the conflict (as if . . . it were the so-called 'judgment of God') determines the side on which justice lies."200 Kant was troubled by the impossibility of rationally making a judgment of right prior to the conflict itself, since in international relations there is "no tribunal empowered to make judgments supported by the power of law."201 Kant returns to the theme of justice as identified with law and legal adjudication. ${ }^{202}$ Because in the international arena there can be no courts backed by force, there can be no rational decision about the justice of a particular war. ${ }^{203}$

How can we reconcile the extreme pacifism voiced in these passages with Kant's acceptance of a decentralized law of nations ${ }^{204}$ and with the analysis of the causes of war as intimately related to the difference in regimes? ${ }^{205}$ As to the first point, Kant's argument for rejecting the possibility of a just war proves too much. For if the absence of international courts with compulsory jurisdiction means that no war can ever be just, then there can be no law of nations at all. There would be no courts to render enforceable judgments about any disputes among nations. There seems to be an inconsistency here. We saw that in the addendum entitled "On the Guarantee for Perpetual Peace," Kant accepted a definition of international law that did not require a sovereign power, courts, legislators, or police-in short, world government. ${ }^{206}$ Perhaps Kant fell prey to his obsession with the definition of law in civil society, which indeed requires courts rendering decisions

do not detract from paramount human rights objective, (3) means used is rights-inspired, and (4) victims welcome intervention).

200. Kant, Perpetual Peace, supra note 1, at 110.

201. Id. Kant concludes that a war of extermination, which extinguishes all rights, is absolutely prohibited because it would achieve perpetual peace only "in the vast graveyard of humanity as a whole." Id.

202. See supra notes 77-81 and accompanying text.

203. Kant reiterates this point in his commentary to the Second Definitive Article.

See Kant, Perpetual Peace, supra note 1, at 116-17.

204. See supra notes $182-185$ and accompanying text.

205. See supra part III.A.

206. See Kant, Perpetual Peace, supra note 1, at 120-25. 
backed by the power of the state. In his discussion of international authority, in contrast, Kant addressed the difficulty and dangers of creating world government by the incorporation of the notion of decentralized enforcement. Yet, decentralized enforcement means that, while war is absolutely banned within the alliance, force will sometimes need to be used by individual states or members of the alliance acting in concert against enemies of the alliance. Therefore, a war of self-defense by a democratic government and its allies against a despotic aggressor is a just war. ${ }^{207}$

The central difficulty with Kant's rejection of just war is the status of tyrannical regimes that have not yet joined the alliance. If the analysis in Part III is correct, the difference in domestic regimes will be a permanent threat to peace. Perhaps one could devise principles of political prudence designed to moderate the historical intolerance of liberal governments toward despots, ${ }^{208}$ but there are at least two thorny problems with Kant's view. The first, already mentioned, concerns the reaction of liberal democracies against aggressive despots. There is no doubt that democratic governments should retain their inherent right of self-defense, ${ }^{209}$ which in Kantian terms is nothing more than the defense of persons by their government against foreign attack. ${ }^{210}$ Second, similar perplexities arise in the case of intervention to stop serious violations of human rights in other states. Kant's Fifth Preliminary Article provides that "no nation shall forcibly interfere with the constitution and government of another."211 In a very succinct commentary, Kant justifies this precept by saying that "[g]enerally, the bad example that one free person furnishes for another ... does not injure the latter."212 For example, a tyrant who tortures his citizens does not injure citizens in neighboring nations.

Leaving aside for the moment the patent inconsistency of this view with the universalist thrust of Kant's thesis, there remains the question whether such an absolute rule of nonintervention can be reconciled with Kant's First Definitive Article, the requirement that states be lib-

207. In his commentary to the Third Preliminary Article, Kant seems to justify war in cases of self-defense. See id. at 108 (distinguishing between "paying men to kill or be killed," which Kant deems "inconsistent with the rights of humanity," and "the voluntary, periodic military training of citizens so that they can secure their homeland against external attack.") (emphasis added); see also Gallie, supra note 11, at 24 (discussing Kant's advocacy of a confederation of common defense against aggression).

208. See, e.g., Doyle, Liberal Legacies (pt. 2), supra note 135 at 343-49.

209. U.N. Charter art. 51 ("Nothing in the present Charter shall impair the inherent right of individual or collective self-defence [sic] if an armed attack occurs against a Member of the United Nations, until the Security Council has taken measures necessary to maintain international peace and security.").

210. See Kant, Perpetual Peace, supra note 1, at 108; cf. Michael Walzer, Just and Unjust Wars 21-32 (1977) (war is crime because it forces people to fight for their rights).

211. Kant, Perpetual Peace, supra note 1, at 109.

212. Id. 
eral democracies. A possible answer would be that nations join the alliance voluntarily, not as a result of intervention, however benign, by liberal members of the alliance. ${ }^{213}$ Voluntary adherence to the alliance means allowing citizens in nonliberal states to resolve their differences among themselves, through their own efforts. In this way, citizens of a nonliberal state could eventually upgrade their society, as it were, so it could become a liberal democracy and qualify as a member. Only through the unfolding of such a process of self-determination will a decision to join the liberal alliance be voluntary; and members of the alliance should patiently wait until that occurs spontaneously and not force the process by intervening.

This reading of Kant is certainly possible. A reading more consistent with the rest of Kant's views, however, is that the nonintervention principle is dependent upon compliance with the First Definitive Article. Internal legitimacy is what gives states the shield of sovereignty against foreign intervention. Since morally autonomous citizens hold rights to liberty, the states and governments that democratically represent them have a right to be politically independent and should be shielded by international law from foreign intervention. ${ }^{214}$ The liberal version of nonintervention and self-determination thus emphasizes respect for human rights and true representation. Political legitimacy is thus seen as the proper foundation of state sovereignty. ${ }^{215}$ The question of internal legitimacy must be resolved prior to the question of nonintervention. 216 Noninterventionism, therefore, follows from whatever theory of internal legitimacy one adopts. If the only just political arrangement is the republican constitution, state sovereignty reacquires its shielding power only in states that have adopted and implemented such a constitution. Sovereignty is to be respected only when it is justly exercised. ${ }^{217}$

213. See, e.g., id. at 115 ("[E]ach nation can and should demand that the others enter into a contract resembling the civil one and guaranteeing the rights of each.").

214. See Doyle, supra note 30 , at 213.

215. The nonintervention principle seems to us a permanent feature of international law, and so it might seem peculiar to see it included by Kant among the Preliminary Articles. Unlike Woodrow Wilson, for example, Kant was indeed a noninterventionist liberal, but what commentators have failed to emphasize is that his being liberal is a precondition of his being noninterventionist. See Waltz, supra note 15 , at 339-40.

216. Even Hinsley, who repeatedly underscores the importance of state sovereignty, writes: "Just as [Kant] derived the right to freedom of the individual from the dictates of a moral law, so he derived the rigbt to freedom of the state-the route to and the guarantee of the freedom of the individual-from the same moral law." Hinsley, supra note 20 , at 63 (emphasis added). The moral law mandates freedom of the individual and freedom of the state as but a means to that end. See Kant, Universal History, supra note 1 , at 34 (problem of just civic constitution cannot be solved without solving international problem).

217. See, e.g., Tesón, supra note 87 , at 82 ; Charles R. Beitz, Political Theory and International Relations 80-83 (1979). 
This suggests that Kant's Fifth Preliminary Article (the prohibition of forcible intervention) might be misplaced. If the protection against intervention is a consequence of domestic legitimacy, then nonintervention holds only among liberal states, and therefore the nonintervention principle should be seen as a definitive precept that governs the liberal alliance, not as a step that must be taken before the alliance is formed.

It follows from these considerations that citizens in a liberal democracy should be free to argue that, in some admittedly rare cases, the only morally acceptable alternative is to intervene to help the victims of serious human rights deprivations. ${ }^{218}$ However, even if Kant is correct on the issue of humanitarian intervention, his rejection of the possibility of just wars is not consistent with the normative individualism underlying the rest of his theory of international law. ${ }^{219}$ While aggression by members against other members of the alliance will be banned forever, in some cases democratic nations must resort to self-help to enforce their rights against outsiders. ${ }^{220}$ At the very least, Kant's view does not account for the case of aggression by despots against members of the alliance. More generally, Kant's reason for rejecting just wars-that there are no courts to determine the justice of the cause-is unconvincing. Kant himself advocates an international law among separate nations that entails a decentralized system of authority. Judgments on the legality of wars are no different from judgments of legality generally, so if there are no courts available for the former, there are no courts available for the latter. Yet, Kant's whole purpose is precisely to show that a law of nations, and judgments of legality in conformity with it, are possible notwithstanding such a decentralization of power.

\section{Why Justice: The Neo-Positivist Theory of Legitimacy}

The attempt to use theories of justice, such as Kantian or Rawlsian social contract theory, as the basis for international law has been recently criticized. Professor Thomas M. Franck argues that theories of justice should not be used as a springboard for determining the legiti-

218. See Tesón, supra note 87 , at 111-23.

219. Kant's view here is also inconsistent with his own rejection of the right to revolution. See supra notes $82-87$ and accompanying text. For it is often the case that the only way for a tyranny to become a liberal democracy, and thus qualify for the alliance, is for citizens violently to overthrow the tyrant. Of course, I have rejected Kant's views on revolution; someone may still salvage Kant's views on the nonintervention issue by disagreeing with him on the revolution issue. My own position is that the right of humanitarian intervention in appropriate cases is an extension of the right to revolution.

220. There is yet another case: the use of force by a nonliberal state against another nonliberal state. The justice of that will depend on whose rights are being violated. Even an illegitimate government may defend citizens against aggression by foreigners. However, despotic governments do not have any right to defend themselves against external force used to remove them from power, provided that such foreign help is welcomed by the victims themselves. See Tesón, supra note 87, at 119-23. 
macy of international rules. ${ }^{221} \mathrm{He}$ maintains that an international rule is deemed legitimate if the governments upon which it operates accept the rule and agree that it accords with generally accepted principles of "right process."222 Professor Franck's definition of "right process" is quite rich, a blend of traditional positivism, critical legal studies, and natural law á la Fuller. According to Franck, legitimacy has four components: determinacy, symbolic validation, coherence, and adherence. ${ }^{223}$

Franck rejects the inclusion of principles of justice as a component of legitimacy. He asserts an operational and a theoretical objection. The operational problem is that justice applies to individuals, while international law addresses states and governments. The theoretical problem with global justice raised by Franck is an old tenet of positivism, namely that the concepts of justice and legitimacy are conceptually distinct. ${ }^{224}$ On this view, justice and legitimacy are two separate concepts which should be carefully kept apart, even though their normative commands may sometimes overlap. ${ }^{225}$ That a rule is legitimate does not mean that it is just and, conversely, many just rules may not be legitimate. This is so even in domestic systems. ${ }^{226}$ Under Franck's theory, the first task is for nations to comply with international law, even if many of its rules are unjust. An international legal system seeks compliance with the rules that participating governments have created, mostly through custom and treaty. ${ }^{227}$

There is much to commend in this account of legitimacy. Professor Franck should be applauded for tackling long-neglected foundational issues in international law. In particular, the notion of right process seems useful as a method for identifying legitimate norms when the international legal system as a whole is just. However, by and large, this view is an extension of the traditional positivist belief that international law is created exclusively by the acts of governments. As such, his theory of international legitimacy is open to a number of objections. ${ }^{228}$

221. See Thomas M. Franck, The Power of Legitimacy Among Nations 208-46 (1990).

222. Id. at 19.

223. Id. at 49. He develops each of these ideas in chapters four through twelve. Franck explains that "symbolic validation" only obtains once the "cues" or symbols that confer legitimacy are perceived to be true which occurs as a result of historical practice and custom.

224. See id. at 208-09.

225. See id. at 242.

226. See id. at 236. Regarding domestic organization, Franck confines his analysis to "secular democracies" maintaining that this bifurcation may not apply to nonwestern "moral communities," see id. at 235.

227. See id. at 210 .

228. For a general critique of consent theory (or positivism), see Tesón, supra note 6, at 99-107. 
The contention that international law emphasizes compliance, not justice, does not merely describe the way international law works, it states a normative proposition. The theory recommends that international lawyers emphasize compliance and order to the detriment of moral considerations. ${ }^{229}$ By requiring that a legitimate norm satisfy the four part test of determinacy, symbolic validation, coherence, and adherence, Franck constructs his own principle of international justice that sacrifices morality and the primacy of respect for individual autonomy in favor of procedural regularity. The idea that order and compliance are a good in and of themselves and, consequently, a valid end of international law is insufficient. Franck's theory amounts to a normative decision that law deserves allegiance irrespective of its substantive content, who created the law, and the extent to which rulers represent their citizens. Franck substitutes political power as the basic determinant of international legitimacy without explanation; he does so at the expense of more important and basic values, such as respect for human rights and fair representation of members of the state.

Second, the operational objection that justice may work among individuals, but not among nations, presupposes the statist paradigm. Professor Franck is correct that the idea of justice among nations seems awkward, but because states are merely representatives, not persons, international justice must also focus on the rights of individuals-the central claim of the Kantian theory of international law. Take, for example, the question of human rights. Kant argued that a world order is just if, and only if, the governments themselves are legitimate, which can only be true if the state's constitution is republican. Despots, who by definition represent no one but themselves, should not play a role in forming international rules. There is no reason why dictatorships ought to be protected under international law and accorded the honorific label of legitimate governments for the purpose of participating in the international legal process. ${ }^{230}$ The first precept of the Kantian theory of international justice is quite simple: international law should not sanction a rule that permits the exercise of tyrannical power. One would think this a basic precept of legitimacy, yet Franck's view claims that domestic rule is a matter of justice which is not, and should not, be addressed by the international system. Once one accepts normative individualism, not statism, Franck's premise must be rejected.

Professor Franck reveals his adherence to the statist paradigm in his discussion of Rawls' theory. Rawls argued that international principles of justice are the ones that would be agreed upon by representatives of nations. These representatives would adopt the principles of equality of nations, self-determination, and nonintervention. ${ }^{231}$ Using the hypothetical example of a genocidal government, Franck correctly

229. See Franck, supra note 221 , at 210.

230. See Tesón, supra note 6 , at 99-103.

231. See supra notes $167-170$ and accompanying text. 
observes that the absolute principle of nonintervention suggested by Rawls leads to unacceptable results from the standpoint of justice. ${ }^{232}$ However, he then reproduces Rawls' mistake of postulating governments as the original contractors and understandably concludes that such a model, which he believes is also supported by the practice of states, would yield the almost absolute nonintervention principle. Furthermore, because noninterventionism is incompatible with elementary notions of justice, at least in extreme cases, he argues that justice, not the absolute nonintervention rule, should be discarded as a component of legitimacy.

This is a rather stunning conclusion in Franck's own positivist terms, because reasoning from state practice yields an inconsistent rule on the question of humanitarian intervention. ${ }^{233}$ Even within the positivist paradigm, in some instances state practice supports intervention. ${ }^{234} \mathrm{It}$ is obvious that governments interested in incumbency and preserving their power and privileges will agree on rules of international law that protect the political space in which they can do as they please. Examples of such rules that protect governments ${ }^{235}$ are the principle of nonintervention, as opposed to humanitarian intervention, and the preservation of territorial integrity, as opposed to the right of secession. ${ }^{236}$ Professor Franck, like several Rawls commentators before him, ${ }^{237}$ acknowledges the problem with considering states and not individuals as the primary subjects of justice. However, he concludes that since rulers insist that interuational law be couched in statist terms, the precepts of justice should not count as components of international legitimacy. His conclusion does not follow logically.

The logical conclusion should be that current international law is wrongly conceptualized in terms of prerogatives of rulers, and that we should move toward a theory of international law that has the individual, not the state, as its subject and basic moral unit. The point that justice makes sense only among individuals not among states is correct, but the conclusion that we must discard justice is incorrect. Instead, the logical corollary should be that international law must be made con-

232. See Franck, supra note 221 , at 221 . The same point is argued at length in Tesón, supra note 87 , at $58-71$.

233. See Tesón, supra note 87 , at 155-200.

234. See Richard Lillich, Humanitarian Intervention: A Reply to Ian Brownlie and Plea for Constructive Alternatives, in Law and Civil War in the Modern World 229, 235-37 (John N. Moore \& Wolfgang G. Friedman eds., 1974).

235. Such rules serve to protect governments although they often use euphemistically collective nouns such as "the people" or "the state." See Fernando R. Tesón, Le Peuple, C'Est Moi! The World Court and Human Rights, 81 Am. J. Int'l L. 173, 181-82 (1987).

236. See the hypothetical example in Franck, supra note 221, at 226-30.

237. See Wicclair, supra note 170, at 297-98; Thomas Pogge, Rawls and Global Justice, 18 Can. J. Phil. 227, 238-39 (1988); Tesón, supra note 87, at 58-64. 
gruent with justice, and thus be conceived in terms of individuals, not states or governments.

By modifying the Rawlsian model in which the contracting parties are individuals or representatives of individuals, not representatives of states, the logical problem of applying the requirements of justice to states is solved. Professor Franck, however, rejects such a model. He concludes that a social contract among individuals or their legitimate representatives, ${ }^{238}$ far from eliminating the rules suggested by Rawls' model that conflict with our moral intuition, would yield an unjust system and fail to accord with reality because it requires that we "imagine two things at once: just nations making a just world."239 Franck maintains that such a system could never appear just from the perspective of the individual because "[ $t$ ]he priorities and sensibilities of rulers, not the people's shared (or intersecting) notions of justice, usually frame the contents of [international] rules and also have the most say in determining their compliance pull."240 His reasoning misses the point. If the Rawlsian model with governments in the original position yields results incompatible with justice, such as precluding intervention in case of a genocidal government, then we should alter the model to accommodate our moral intuitions, rather than forsake justice.

The statist paradigm is precisely what is wrong. To say that a theory of international justice centered on the individual is unjust because current international law is created by and for governments begs the question of why justice should be a component of legitimacy. If part of what a normative theory of international law wants to do is evaluate the behavior of states in the light of what is right, then the standard cannot be the very behavior of states. What the Kantian thesis suggests is that domestic justice must be the first priority of the international system both because that is intrinsically right and because it is causally linked to peace and, by extension, to all other important global challenges. ${ }^{241}$

Franck's theory is also open to the objection raised by Kant's empirical argument. ${ }^{242}$ If international law validates tyrannical governments as legitimate members of the international community, it interferes with the purpose of achieving peaceful cooperation needed to meet pressing global challenges. If Kant and Doyle are right that nonliberal governments are naturally prone to aggression, the chance of getting them to work for peace and mutual understanding is indeed

238. See supra note 195 and accompanying text; see also David A. J. Richards, International Distributive Justice, 24 Nomos 275, 282 (1982) (arguing for plausibility of contractarian theory to provide foundations for moral duties in international area).

239. Franck, supra note 221, at 226, 233.

240. Id.

241. Professor Franck includes among these challenges the control of arms, ozone depletion, desertification, hunger, and virulent disease. See id. at 2I0. One would think that all these tasks are instrumental in achieving the two most important global ends: freedom and peace.

242. See supra part III.A. 
slim. The international community would be admitting a Trojan Horse in its midst. Franck's deceptively realistic approach, obsessed with compliance, will in the end result in the defeat of the very ends that international law was supposed to pursue.

The more natural approach is this: Insofar as international law addresses governments, it does so in their capacity as agents of persons, as representatives. This in turn raises the question of representation as an international matter. The agency relationship itself must be subject to international scrutiny. Individuals who claim to represent a nation but in fact have seized power by brute force should not be accepted as members of the community that makes the law. There is every reason to extend these common sense notions of justice to international relations and include them in a definition of international legitimacy.

State-oriented theories of international law like Franck's propose a double paradigm for the ordering of individuals: one for international law and the other for domestic law. ${ }^{243}$ Justice and legitimacy are always conceptually separate, ${ }^{244}$ but whereas in domestic law justice permeates legitimacy, in the international legal system the main goals are order and compliance. In contrast, the Kantian theory of international law rejects this dual paradigm and dual purpose, attempts to unify our theory of justice, and makes legitimacy depend on justice. ${ }^{245}$ Thus, there is only one theory of justice, embracing both global and national institutional arrangements. ${ }^{246}$

Any theory of international or domestic justice attempts to put forward principles which amount to an ideal standard for adjudicating competing claims in a scheme of social cooperation. Thus, the Kantian theory of international law contends that a morally just world order comprises nation-states that are internally just and whose governments therefore represent individuals. The rights and interests of individuals form the ultimate touchstone of the theory. Along with this substantive thesis, the theory must provide a notion of formal justice or legitimacy not altogether different from the one Professor Franck suggests.

Once one leaves the domain of ideal theory, many rules enacted by

243. See Franck's discussion of pacta sunt servanda: for domestic law,.in which justice reigns, he argues that principle is justified by moral sacredness of promises. For international law, in which order controls, the justification is stahility. See Franck, supra note 221 , at $234-36$.

244. See id. at 242.

245. Franck does appreciate the importance of justice. He writes: "As the firm outlines of world order become readily apparent, and as that order increasingly focuses on the individual's place in global society, a keener understanding of the theory, function, and power of justice must surely move to the top of the agenda." Id. at 246. Yet, he settles for the statist paradigm and rejects the view that justice should be the basis of legitimacy and international law.

246. Cf. Lea Brilmayer, Justifying International Acts 157, 159 (1989) (agreeing with unity of domestic and international theory from methodological standpoint but rejecting notion that justice underlies theory of legitimacy). 
governments, even representative governments that respect human rights, may be unjust. What is the role of ideal theory in those cases? First, international rules enacted through right process are legitimate provided that the system as a whole is just. ${ }^{247}$ For example, if just goveruments agree by treaty to a uniform tax, which upon reflection is considered contrary to notions of distributive justice, the tax may be collected legitimately nonetheless, because the basic requirement of justice that the rule be agreed upon by representative governments that respect basic human rights has been fulfilled. The Kantian theory, far from rejecting right process, makes it a central feature of international law second only to the elementary precepts of justice.

The second function of an ideal theory, such as the Kantian theory, is to achieve determinacy of the rules of international law. ${ }^{248}$ Treaties and custom should be interpreted in the light of appropriate principles of justice; there is no such thing as objective state practice. The behavior of governments cannot be normatively understood without presupposing a moral-political judgment. ${ }^{249}$ In order to glean a normative pattern or a rule from diplomatic history, one must interpret that history and draw from it the best normative teachings. Thus, ideal theory, far from being "wishful thinking," 250 performs the double role of being an impulse for reform in those cases in which the behavior of states conflicts with the theory's basic tenets; and, in bard cases, of providing standards of interpretation that will make international law consistent with the precepts of justice.

On the other hand, the Kantian theory of international law cannot be seen merely as a rational reconstruction of the actual rules and principles of international law. Some rules may be so much in conflict with the theory that all we can say is that they ought to be repealed or ignored. Yet in those cases in which the practice of states can be interpreted in accordance with the theory, justice becomes the major component of legitimacy.

\section{CODA}

The Kantian theory is not limited to a rarified philosophical domain. The theory yields practical solutions in many fields. First, the theory mandates the creation of compulsory judicial mechanisms to settle controversies arising from the three Definitive Articles: an Interna-

247. See Rawls, supra note 61 , at $350-55$ (discussing "the duty to comply with an unjust law").

248. See Tesón, supra note 87, at 6, 11, 200 (arguing that countries do not disagree on whether to follow international law, but rather on what that law dictates); Tesón, supra note 6 , at 85-89 (same).

249. See sources cited supra note 248; Charles de Visscher, Theories et Realités en Droit International Public 171 (1970) (normative force of custom is result of lawyer "reconstituting" facts in light of moral imperatives).

250. See Franck, supra note 221, at 233. 
tional Court of Human Rights, the International Court of Justice, and an International Court of Trade (roughly corresponding to Kant's three Definitive Articles respectively). Second, the Kantian theory also necessitates amendment of the conditions of admission and permanence in the United Nations. Articles 4 and 6 of the Charter of the United Nations should be amended to include the requirement that only democratic governments that respect human rights should be allowed to represent members, and that only democratic states will be accepted as new members. ${ }^{251}$ Third, the law of treaties must undergo important changes. Representatives of dictators must be disenfranchised for the purposes of expressing the state's consent to be bound by the treaty. ${ }^{252}$ Fourth, the law of diplomatic relations should be amended to deny diplomatic status to representatives of illegitimate governments. ${ }^{253}$ Finally, the law of recognition should prohibit recognition of illegitimate governments, along the lines suggested by President Woodrow Wilson in the beginning of this century 254 and by the International Court of Justice for South Africa in the Namibia opinion. ${ }^{255}$ These and other reforms will have to be worked out in detail, and many variations consistent with the Kantian theory are possible.

251. Article 4 of the U.N. Charter reads: "Membership in the United Nations is open to all other peace-loving states which accept the obligations contained in the present Charter and, in the judgment of the Organization, are able and willing to carry out these obligations." U.N. Charter art. 4, $\uparrow 1$. While article 4 may conceivably be read as requiring respect for human rights from prospective members, the main organs of the United Nations have not interpreted it so. For a summary of the practice, see Guy Feuer, Article 4, in La Charte Des Nations Unies 171-72, 177-79 (Jean-Pierre Cot \& Alain Pellet eds., 1985).

252. See, e.g., article 7 of the Vienna Convention on the Law of Treaties, in which the only requirement for considering a person as representing a state for the purposes of expressing the consent to be bound by a treaty is that such person produce "appropriate full powers." Vienna Convention on the Law of Treaties, art. 7, U.N. Doc. A/ Conf. 39/27, 5, 8 I.L.M. 683 (1969).

253. Articles 2, 4 and 7 of the Vienna Convention on Diplomatic Relations give almost unlimited discretion to sending and receiving states, so in theory it allows for the receiving state either to refuse to establish diplomatic relations with a tyrannical government, or to deny agrément to representatives of illegitimate governments. Vienna Convention on Diplomatic Relations, Apr. 18, 1961, art. 2, 4, 7, 23 U.S.T. 3227, 500 U.N.T.S. 95. There is a difference between denying agrément to the individual because of his or her past or other circumstances, and denying the agrément because the envoy is not representative of the sending state. The practice of states, however, has not shown much concern for true representativeness, with one exception: South Africa. The General Assembly recommended members to sever diplomatic relations with South Africa as early as 1962. See Ludwik Dembinski, The Modern Law of Diplomacy 92 (1988). South Africa is a clear case of internal illegitimacy for lack of representativeness and serious human rights deprivations. The principle governing that case should be extended to other cases of tyranny.

254. See Wilson's famous Mobile statement, 7 Am. J. Int'l L. 331 (1913) (discussing United States' desire only to deal with just governments in Central and South America).

255. See Namibia Opinion, 1971 I.C.J. 16, 58, I 133 (June 21) (obligation by states not to recognize South Africa's illegal occupation of Namibia because of South Africa's human rights violations in Namibia). 
One of the most remarkable developments since the end of the Second World War has been the exponential growth of individual liberty-the impressive expansion of human rights and democracy to societies that had been excluded from the benefits of freedom. This extraordinary and, for many, unexpected development disproves the claim that human rights and democracy are just the luxury of industrial societies and lends credence to the assumption that every rational person, regardless of historical or cultural circumstance, is apt to value and pursue freedom both as an intrinsic good and as the necessary means to formulate and act upon rational plans of life.

This enlightened moral and political global reality is ill-served by the statist model of international law. The model promotes states and not individuals, governments and not persons, order and not rights, compliance and not justice. It insists that rulers be permitted to exercise whatever amount of coercion is necessary to politically control their subjects. Yet, the reasons to prefer a world of free nations are strong enough to place the burden of proof on international lawyers who cling to the traditional statist paradigm that privileges power-holders and ignores people. If some empirical confirmation is required, recent events in the Persian Gulf should teach us at least the lesson that things would have been very different had the states in the region been liberal democracies of the kind defended here.

Perhaps there is no necessary link between the political triumph of human rights and democracy and the theoretical foundations of international law and politics. Perhaps all we can say is that the wind is blowing now in the direction of individual freedom and that the historical cycle will before long see nations return to despotism and gross injustice. It is indeed possible that the optimism caused by the triumph of human rights is hasty and that the celebration is therefore premature. ${ }^{256}$ Yet, if the tide is going to turn against individual freedom, it will be the product of human design, not of the forces of nature pushing us around. It follows that we have to construct and defend our global institutions if we want them to last.

International law can make an important contribution in this respect. We must rethink and reconstruct international law in a way that incorporates and recognizes that the ultimate aim of global institutional arrangements is to foster the development of each individual's full po-

256. Recall the warnings of former Soviet Foreign Minister Shevardnadze, who resigned in protest of Gorbachev's courtship of the hardliners which he felt would lead toward the reestablishment of totalitarianism in the U.S.S.R., Tom Wicker, An Ominous Warning, N.Y. Times, Dec. 23, 1990, at O11. These warnings proved to be accurate: in the last week in August 1991, a coup d'état in the Soviet Union succeeded in reestablishing a dictatorship for a couple of days. Freedom and democracy, however, re-emerged with renewed force after the restoration of the legitimate government. The adherence to the liberal alliance by the nations that succeeded the now extinct Soviet Union will be perhaps the most encouraging event of the century. 
tential as an autonomous human being, to protect freedom. This is so even if pessimist forecasters are right that we should expect significant setbacks to freedom globally in the years to come. Moreover, international law does not merely describe international behavior, so that our conceptual model would be more or less statist depending on the progress or restriction of human rights around the world. Rather, international law purports to set standards of international behavior. Judgments of legality are evaluations of diplomatic history according to that standard. It is insufficient to verify that many governments ignore the precepts of justice and conclude that justice should be discarded. The better view includes moral analysis as an integral part of international law. The alternative positivist paradigm, by clinging to the deceptively simple notion of the unrestrained practice of states as the touchstone for legitimacy, ends up surrendering to tyranny and aggression, the evils that international law was intended to control in the first place.

Kant's accomplishment in the field of international theory and ethics is magnificent. Few other thinkers have successfully combined so many disparate elements of morality, politics, epistemology, and history in a theory of international law. The community of free nations envisioned by Kant will hopefully expand gradually and maintain itself, as it has done for the past two hundred years, and the aim of perpetual peace will be achieved the moment when the liberal alliance comprises every civil society. It is never too late to replace the grim view of a world order in which naked political power is the standard of legitimacy with Kant's inspired cosmopolitan vision of moral progress in which tribute is paid to the definitive traits of humanity-freedom and reason. 